\title{
Insights into the relationship between toll like receptors and gamma delta T cell responses
}

\author{
Asif Amin Dar, Rushikesh Sudam Patil and Shubhada Vivek Chiplunkar* \\ Chiplunkar Laboratory, Advanced Centre for Treatment, Research and Education in Cancer (ACTREC), Tata Memorial Centre, Navi Mumbai, India
}

Edited by:

Anton G. Kutikhin, Russian Academy

of Medical Sciences, Russia

\section{Reviewed by:}

Isaias Glezer, Universidade Federal de São Paulo, Brazil

Rajesh Kumar Sharma, University of Louisville, USA

\section{*Correspondence:}

Shubhada Vivek Chiplunkar, Chiplunkar Laboratory, Advanced

Centre for Treatment, Research and Education in Cancer (ACTREC), Tata Memorial Centre, Sector 22 Kharghar, Navi Mumbai, Maharashtra 410210, India

e-mail:schiplunkar@actrec.gov.in
The tumor microenvironment is an important aspect of cancer biology that contributes to tumor initiation, tumor progression and responses to therapy. The composition and characteristics of the tumor microenvironment vary widely and are important in determining the anti-tumor immune response. Successful immunization requires activation of both innate and adaptive immunity. Generally, immune system is compromised in patients with cancer due to immune suppression, loss of tumor antigen expression and dysfunction of antigen presenting cells (APC). Thus, therapeutic immunization leading to cancer regression remains a significant challenge. Certain cells of the immune system, including dendritic cells (DCs) and gamma delta $(\gamma \delta)$ T cells are capable of driving potent anti-tumor responses. The property of MHC-unrestricted cytotoxicity, high potential of cytokine release, tissue tropism and early activation in infections and malignant disease makes $\gamma \delta \mathrm{T}$ cells as an emerging candidate for immunotherapy. Various strategies are being developed to enhance anti-tumor immune responses of $\gamma \delta$ T cells and DCs one of them is the use of novel adjuvants like toll like receptors (TLR) agonists, which enhance $\gamma \delta$ T cell function directly or through DC activation, which has ability to prime $\gamma \delta T$ cells. TLR agonists are being used clinically either alone or in combination with tumor antigens and has shown initial success in both enhancing immune responses and eliciting anti-tumor activity. TLR activated $\gamma \delta T$ cells and DCs nurture each other's activation. This provides a potent base for first line of defense and manipulation of the adaptive response against pathogens and cancer. The available data provides a strong rationale for initiating combinatorial therapy for the treatment of diseases and this review will summarize the application of adjuvants (TLRs) for boosting immune response of $\gamma \delta$ T cells to treat cancer and infectious diseases and their use in combinatorial therapy.

Keywords: immunotherapy, $\gamma \delta \mathrm{T}$ cells, toll like receptors, tumors, dendritic cells

\section{INTRODUCTION}

Innate and adaptive immune responses are sentinels of host against the diverse repertoire of infectious agents (viruses and bacteria) and cancer. Both components of immune system identify invading microorganisms or damaged tissues as non-self and activate immune responses to eliminate them. Efficient immune responses depend upon how close an interaction is between the innate and adaptive immune system. $\gamma \delta \mathrm{T}$ cells and toll like receptors (TLR) serve as an important link between the innate and adaptive immune responses (1-3). Extensive studies have suggested that $\gamma \delta \mathrm{T}$ cells play important roles in host defense against microbial infections, tumorigenesis, immunoregulation and development of autoimmunity. $\gamma \delta \mathrm{T}$ cells also have several innate cell-like characters that allow their early and rapid activation following recognition of cellular stress and infection $(4,5)$. However to accomplish these functions, $\gamma \delta \mathrm{T}$ cells use both the T cell receptor (TCR) and additional activating receptors (notably NKG2D, $\mathrm{NOTCH}$, and TLR) to respond to stress-induced ligands and infection. $\gamma \delta \mathrm{T}$ cells express TLRs and modulate early immune responses against different pathogens (6). In this review, we summarize and discuss some of the recent advances of the $\gamma \delta \mathrm{T}$ cell biology and how direct control of $\gamma \delta \mathrm{T}$ lymphocyte function and activation is monitored by TLR receptors and ligands. The review highlights involvement of TLR signaling in $\gamma \delta \mathrm{T}$ cell functions and their implications in harnessing $\gamma \delta \mathrm{T}$ cells for cancer immunotherapy.

\section{$\gamma \delta$ T CELLS, ANATOMICAL DISTRIBUTION AND ANTIGENIC DIVERSITY}

Based on the type of TCR they express, T lymphocytes can be divided into two major subsets, $\alpha \beta$ and $\gamma \delta$ T cells. $\gamma \delta$ T cell represents a small subset of T lymphocytes (1-10\%) in peripheral blood. While in anatomical locations like small intestine, $\gamma \delta \mathrm{T}$ cells comprise a major bulk of $\mathrm{T}$ cells $(25-60 \%$ in human gut) (7). $\gamma \delta \mathrm{T}$ cells are the first $\mathrm{T}$ cells to appear in thymus during $\mathrm{T}$ cell ontogeny in every vertebrate (8), which suggests that their primary contribution could be neonatal protection because at this point conventional $\alpha \beta \mathrm{T}$ cell responses are severely functionally impaired and DCs are immature (9). In neonates, the $\mathrm{V} \delta 2^{+}$cells derived from human cord blood showed early signs of activation. These cells secrete IFN- $\gamma$ and express perforin after short-term in vitro stimulation (10). In comparison to the neonate derived $\alpha \beta$ T cells of peripheral blood, $\gamma \delta \mathrm{T}$ cell subset produces copious amount of IFN- $\gamma$ and are precociously active (11). Hence, $\gamma \delta$ 
T cells are well engaged in newborns to contribute to immuneprotection, immune-regulation and compensate for impaired $\alpha \beta$ T cell compartment.

$\gamma \delta \mathrm{T}$ cells are unconventional $\mathrm{CD}^{+}{ }^{+} \mathrm{T}$ cells and differ from the conventional $\alpha \beta \mathrm{T}$ cells in their biology and function (Table 1). Although a sizeable fraction of $\gamma \delta \mathrm{T}$ cells in the intraepithelial lymphocyte compartments of human and mice are CD $8 \alpha \alpha^{+}$but the peripheral blood $\gamma \delta$ T cells are predominantly double negative $\left(\mathrm{CD} 4^{-} \mathrm{CD}^{-}\right) \mathrm{T}$ cells. The absence of CD4 or CD8 expression on majority of the circulating $\gamma \delta \mathrm{T}$ cells is well in line with the fact that antigen recognition is not $\mathrm{MHC}$ restricted $(12,13)$. Crystal structure analysis of the $\gamma \delta$ TCR revealed that $\gamma \delta$ TCR is highly variable in length resembling immuno-globulins (Ig) more than the $\alpha \beta$ TCR. The antigen recognition property of $\gamma \delta \mathrm{T}$ cells is fundamentally different from $\alpha \beta$ T cells but similar to antigenantibody binding, which is more likely to occur independent of MHC cross presentation (14). However, recently butyrophilin BTN3A1, a non-polymorphic ubiquitously expressed molecule was identified as an antigen presenting molecule of $\mathrm{V} \gamma 9 \mathrm{~V} \delta 2 \mathrm{~T}$ cells. Soluble BTN3A1 binds (Isopentenyl diphosphate) IPP and (E)-4-hydroxy-3-methyl-but-2-enyl diphosphate (HMBPP) with different affinities in 1:1 ratio to stimulate $\gamma \delta$ T cells (15).

The important feature of $\gamma \delta \mathrm{T}$ cells is their tropism to epithelial tissues. With respect to anatomical localization, $\gamma \delta \mathrm{T}$ cell population can be divided into two groups: lymphoid-homing $\gamma \delta \mathrm{T}$ cells that can be primed in the circulation and clonally expand in a conventional "adaptive" manner; and innate-like cells that respond rapidly and at a relatively high frequency in many tissue sites. Migration and anatomical localization of T lymphocytes is crucial for their antigen specificity and maintaining homeostasis in the mammalian immune system. Although $\gamma \delta \mathrm{T}$ cells are well represented among peripheral blood mononuclear cells (PBMC) and in afferent and efferent lymph, they are rarely found in lymph node parenchyma, spleen, Peyer's patches and thymus. Moreover, unlike $\alpha \beta$ T cells, splenic $\gamma \delta$ T cells, if present, are not confined to the lymphoid areas (the white pulp) but are also found throughout the red pulp of spleen and marginal zones of cell trafficking (16). $\gamma \delta \mathrm{T}$ cells are abundantly present in the epithelia of skin, genital and intestinal tract (17). In the small intestines of humans, mice, chickens and cattle, $\gamma \delta \mathrm{T}$ cells comprise a substantial fraction of intestinal intraepithelial lymphocytes (IELs); in mice $\gamma \delta^{+}$
IELs constitute $50-60 \%$ of the IEL pool (18-20). The epidermal $\gamma \delta^{+}$IELs of mice and cattle (but not humans) have a marked dendritic morphology and are hence known as dendritic epidermal T cells (DETCs) (21). DETCs are maintained at steady state in normal adult murine skin but on activation execute specialized functions like tissue repair (22). DETCs also maintain keratinocyte homeostasis, which along with Langerhan cells forms its neighborhood (23). Under pathological conditions, $\gamma \delta \mathrm{T}$ cells quickly expand and infiltrate into lymphoid compartments and other tissues.

Another striking difference between $\alpha \beta$ and $\gamma \delta$ T cells is the range of antigens or ligands that are recognized by the respective TCRs. Unlike $\alpha \beta \mathrm{T}$ cells, which recognize protein antigen processed inside the cell and presented by MHC molecules, $\gamma \delta$ $\mathrm{T}$ cells recognize antigens like B cells as revealed by structural and functional studies (24). $\gamma \delta$ T cells can respond to a variety of stimuli irrespective of their molecular or genetic nature. In mice, the non-classical MHC class I molecules T10 and T22 are recognized by $\gamma \delta \mathrm{T}$ cells (25-28). Similar to T10 and T20, murine class II MHC (IA) antigens IE and IA are identified to act as ligands for $\gamma \delta$ $\mathrm{T}$ cell clones $(29,30)$. In addition, herpes glycoprotein GI-reactive $\gamma \delta \mathrm{T}$ cell clones protect mice from herpes simplex virus (HSV) induced lethal encephalitis $(31,32) . \gamma \delta$ TCRs can also bind to an algal molecule, phycoerythrin inducing upregulation of CD44 and downregulation of CD62L in $\gamma \delta \mathrm{T}$ cells (33). B6 murine splenic and hepatic $\gamma \delta \mathrm{T}$ cells respond to cardiolipin (bacterial cell-wall phospholipid and endogenous component of mitochondria) presented by CD1d molecules (34). Insulin derived peptide B:9-23 is also recognized by the $\gamma \delta \mathrm{T}$ cell clones derived from non-obese diabetic mice (NOD mice) (35). SKINT1, a mouse immunoglobulin superfamily member, bears structural similarity to human CD277 (butyrophilin 3A1) and is expressed by medullary thymic epithelial cells (mTECs) and keratinocytes that is crucial for the development of $\mathrm{V} \gamma 5 \mathrm{~V} \delta 1^{+}$DETCs (36).

In humans, majority of $\gamma \delta \mathrm{T}$ cells express a rearranged $\mathrm{T}$ cell receptor (TCR) composed of $\mathrm{V} \gamma 9$ and $V \delta 2$ domains; thus, this population is referred to as $\mathrm{V} \gamma 9 \mathrm{~V} \delta 2$. The $\mathrm{V} \gamma 9 \mathrm{~V} \delta 2 \mathrm{~T}$ cells recognize self and microbial phosphorylated metabolites generated in eukaryotic mevalonate pathway and in the microbial 2-C-methyl-derythritol 4-phosphate (MEP) pathway (37). Initially, it was reported that the non-peptidic ligands isolated from mycobacterial cell lysates were

Table 1 | Comparison between $\alpha \beta$ and $\gamma \delta$ T cells.

\begin{tabular}{|c|c|c|}
\hline S.No. & $\alpha \beta$ T cells & $\gamma \delta$ T cells \\
\hline 1 & Constitutes about $65-70 \%$ of total PBMCs & Constitutes about $1-10 \%$ of total PBMCs \\
\hline 2 & $\begin{array}{l}\text { Recognize the processed peptide antigen with the help } \\
\text { antigen presenting molecule } \mathrm{MHC} 1 \text { and } \mathrm{MHC} \|\end{array}$ & $\begin{array}{l}\text { Do not show } \mathrm{MHC} \text { restriction but may require the antigen presenting } \\
\text { molecule Butyrophilin } 3 \mathrm{~A} 1 \text { molecule }\end{array}$ \\
\hline 3 & Express either $\mathrm{CD}^{+}$or $\mathrm{CD}^{+}$ & Mostly double negative, murine intestinal IELs may be CD8 $\alpha \alpha^{+}$ \\
\hline 4 & TCR junctional diversity is very diverse & TCR junctional diversity is small \\
\hline 5 & Do not show tissue tropism & Show tissue tropism \\
\hline 6 & $\alpha \beta T$ Cells response is late & $\gamma \delta T$ cells respond earlier \\
\hline 7 & Regulatory phenotype is attributed to $\mathrm{CD} 4^{+} \mathrm{CD} 25^{+} \mathrm{T}$ cells & $\begin{array}{l}\text { Regulatory phenotype is attributable to various subsets, including murine } \\
\mathrm{V}_{\gamma} 5^{+} \text {DETCs and human } \mathrm{V}_{\gamma} 1^{+} \text {peripheral cells }\end{array}$ \\
\hline
\end{tabular}


stimulatory for $\mathrm{V} \gamma 9 \mathrm{~V} \delta 2 \mathrm{~T}$ cell clones. Later, IPP, an intermediate metabolite of the mevalonate pathway, was isolated and identified as a stimulatory molecule. Characterization of the microbial antigens recognized by human $\gamma \delta$ T cells predicted that these are non-proteinaceous in nature and have critical phosphate residues $(37,38)$. Subsequent studies, conducted with M. tuberculosis, identified HMBPP, an intermediate metabolite of the MEP pathway, as a strong agonist of $\gamma \delta$ TCR. The measured potencies of IPP and HMBPP show an enormous difference. The ED50 of IPP is $\sim 20 \mu \mathrm{M}$, whereas that of HMBPP is $\sim 70 \mathrm{pM}$, i.e., more than 105 times lower (38).

Another stimulatory molecule is Staphylococcus aureus enterotoxin A (SEA) that directly interacts with the TCR V $\gamma 9$ chain independently of the paired $V \delta$ chain. The mechanism of recognition of this superantigen is different from that of phosphorylated metabolites and requires the interaction with MHC class II molecules. $\gamma \delta$ T cells kill target cells and release cytokines upon interaction with SEA but do not proliferate (39).

Recently, the TCR from a $\gamma \delta \mathrm{T}$ cell clone derived from a cytomegalovirus (CMV)-infected transplant patient was shown to directly bind to endothelial protein $\mathrm{C}$ receptor (EPCR), which is a lipid carrier with a similar structure to CD1, showing again that $\gamma \delta$ TCR engagement is cargo independent (40). ATP F1 synthase has been identified as stimulatory ligand of the TCR V $\gamma 9 \mathrm{~V} \delta 2$. ATP F1 synthase is an intracellular protein complex involved in ATP generation. However, optimal responses of $\mathrm{V} \gamma 9 \mathrm{~V} \delta 2 \mathrm{~T}$ cells by tumor target cell lines expressing F1-ATPase requires apolipoprotein A1. A monoclonal antibody interacting with apolipoprotein A1 was shown to inhibit TCR $\gamma \delta$ activation as it disrupted the trimolecular complex of ApoA1, ATP F1 synthase, and $\gamma \delta$ TCR required for optimal response (41).

The second major population of human $\gamma \delta$ T cells utilizes the $\mathrm{V} \delta 1$ chain, which pairs with a variety of $\mathrm{V} \gamma$ chains. This subset of $\mathrm{V} \delta 1^{+} \mathrm{T}$ cells is mainly found in tissues and is activated by CD1c and CD1d-expressing cells. The group 1 CD 1 molecules have ability to present lipid A to human $\gamma \delta$ T cells. The human $\gamma \delta$ T cells also recognize the related group $2 \mathrm{CD} 1$ molecule as CD1d/lipid complex. Phosphatidyl ethanol amine (PE), a phospholipid, activates $\gamma \delta$ T cells in a CD1d manner dependent suggesting its CD1d restricted recognition (42). In addition, some populations of $\gamma \delta \mathrm{T}$ cells in normal human PBMCs also recognize lipid molecules such as cardiolipin (a marker of damaged mitochondria), sulfatide (a myelin glycosphingolipid), or $\alpha$-galactosylceramide ( $\alpha$-GalCer) in association with CD1d, which are noted ligands of natural killer $\mathrm{T}$ (NKT) cells $(34,43-45)$. Human $\gamma \delta \mathrm{T}$ cells also recognize the stress-induced MHC class I-related MICA/MICB molecules and the UL16-binding proteins that are upregulated on malignant or stressed cells (46-48). Heat shock proteins (HSPs) expressed on the cell membrane play an important role in cancer immunity. Hsp60 expressed on oral tumors act as ligand for $\mathrm{V} \gamma 9 \mathrm{~V} \delta 2 \mathrm{~T}$ cells $(49,50)$. Hsp60 and Hsp70 expressing human oral and esophageal tumors are lysed by $\mathrm{V} \gamma 9 \mathrm{~V} \delta 2 \mathrm{~T}$ cells (49-51). Hsp72 expressing neutrophils were rapidly killed by $\gamma \delta \mathrm{T}$ cells through direct cell to cell contact, indicating that hsp72 expression on cell surface pre-disposes inflamed neutrophils to killing by $\gamma \delta \mathrm{T}$ cells (52). In Another study, hsp90 expression on EBV infected B cells rapidly promoted $\gamma \delta$ $\mathrm{T}$ cell proliferation (53). This confirms that $\gamma \delta \mathrm{T}$ cells recognize qualitatively distinct antigens, which are profoundly regulated by their anatomical localization.

\section{CO-RECEPTORS AND $\gamma \delta$ T CELL ACTIVATION}

Most $\gamma \delta \mathrm{T}$ cells respond to non-peptidic antigens even in the absence of antigen presenting cells (APCs). However, the presence of APCs can greatly enhance the $\gamma \delta \mathrm{T}$ cell response (54). This suggests that accessory molecules/receptors may be involved in effector functions of these cells. Some of important co-receptors used by $\gamma \delta$ T cells include NOTCH, NKG2D, and TLR (55).

Our study has identified Notch as an additional signal contributing to antigen specific effector functions of $\gamma \delta \mathrm{T}$ cells. We have shown that $\gamma \delta \mathrm{T}$ cells express Notch1 and Notch 2 at both mRNA and protein level. Inhibition of Notch signaling in antiCD3 MAb stimulated $\gamma \delta \mathrm{T}$ cells resulted in marked decrease in proliferation, cytotoxic potential, and cytokine production by $\gamma \delta$ T cells confirming the involvement of Notch signaling in regulating antigen specific responses of $\gamma \delta \mathrm{T}$ cells (55).

$\gamma \delta \mathrm{T}$ cells express NKG2D on their cell surface resulting in their activation. Treatment of PBMC with immobilized NKG2Dspecific $\mathrm{mAb}$ or NKG2D ligand MHC class I related protein A (MICA) resulted in the up-regulation of CD69 and CD25 on $\mathrm{V} \gamma 9 \mathrm{~V} \delta 2$. Furthermore, NKG2D increased the production of TNFalpha and release of cytolytic granules by $\mathrm{V} \gamma 9 \mathrm{~V} \delta 2 \mathrm{~T}$ cells (56). Later, it was shown that the protein kinase $\mathrm{C}$ transduction pathway as a main regulator of the NKG2D-mediated costimulation of anti-tumor $\mathrm{V} \gamma 9 \mathrm{~V} \delta 2 \mathrm{~T}$ cell cytolytic response (57).

TLR agonists are also known to trigger the early activation and the IFN- $\gamma$ secretion by $\mathrm{V} \gamma 9 \mathrm{~V} \delta 2 \mathrm{~T}$ cells (58). TLR ligands indirectly increase the anti-tumoricidal activity of $\mathrm{V} \gamma 9 \mathrm{~V} \delta 2 \mathrm{~T}$ cells (59). In this review, we will focus on TLR as an additional co-receptor modulating the function of immune cells with special focus on $\gamma \delta$ T cells.

\section{TOLL LIKE RECEPTOR AND IMMUNE CELLS}

The immune system functions in anti-microbial defense by recognizing groups of molecules unique to microorganisms (60). These unique microbial molecules are called pathogen-associated molecular patterns (PAMPs) and are recognized by a family of cellular receptors called pattern recognition receptors (PRRs) (61). TLRs along with retinoic acid-inducible gene (RIG)-I-like receptors (RLRs) and nucleotide-binding oligomerization domain (NOD)-like receptor (NLRs) are prototype PPRs, which recognize pathogen-associated molecular patterns (PAMPs) from microorganisms or danger-associated molecular patterns (DAMPs) from damaged tissues (62). Recognition of PAMPs by TLRs trigger release of inflammatory cytokines and type 1 interferon's (IFN) for host defense $(60,63-65)$. The adaptive immune system, on the other hand, is responsible for elimination of pathogens in the late phase of infection and in the generation of immunological memory mediated by B and T cells (66).

TLRs derived their name from Drosophila melanogaster Toll protein based on their homology (67). In mammals, till date 13 members of TLR family has been identified $(63,68-71)$. TLR1-9 is conserved in humans and mice while TLR10 is non-functional in mice because of a retroviral insertion while TLR11-13 is lost from the human genome. The first TLR identified was TLR4 
and recognizes bacterial lipopolysaccharide (LPS) from Gramnegative bacteria $(67,72,73)$. TLRs are classified into several groups based on the types of PAMPs they recognize. TLR1, 2, 4 and 6 recognize lipids whereas the highly related TLR7, TLR8 and TLR9 recognize nucleic acids. Murine TLR11 recognizes a protozoan derived profilin-like protein while TLR13 recognizes Vesicular stomatitis virus (63). TLRs are localized in the distinct cellular compartments, for example; TLR1, TLR2, TLR4, TLR5, TLR6, and TLR11 are expressed on the cell surface whereas TLR3, TLR7, TLR8 TLR9, TLR11, TLR12 and TLR13 are expressed in intracellular vesicles such as the endosome and ER. The intracellular TLRs are transported to the intracellular vesicles via UNC93B1, a trans-membrane protein, which is localized in the ER of the cell $(70,71,74-77)$. TLR family receptors have a common structural architecture. TLRs are type I integral membrane glycoproteins characterized by multiple extracellular leucine-rich repeats (LRRs) and a single intracellular Toll/interleukin-1 (IL-1) receptor (TIR). TLRs mostly form homo-dimers with a few exceptions, which form heterodimers to trigger a signal. For example, TLR2 forms heterodimers with TLR1 or TLR6 enabling differential recognition of lipopeptides. The TIR domain of TLRs is required for the interaction and recruitment of various adaptor molecules to activate downstream signaling pathway. After recognizing PAMPs, TLRs activate intracellular signaling pathways that lead to the induction of inflammatory cytokine genes such as TNF- $\alpha$, IL-6, IL-1 $\beta$ and IL-12 through the recruitment of adaptors such as MyD88, TRIF, TRAM, TIRAP and SARM1 (78). MyD88 is a universal adaptor used by all TLRs, except TLR3, to induce inflammatory pathways through activation of MAP Kinases (ERK, JNK, p38) and transcriptional factor NF- $\mathrm{KB}$ (63, 79). TLR3 and TLR4 use TRIF to bring activation of alternative pathway (TRIF-dependent pathway) through transcription factors IRF3 and NF- $\mathrm{KB}$ to induce type 1 IFN and inflammatory cytokines (80-82). TRAM selectively participates in the activation of the TRIF-dependent pathway downstream of TLR4, but not TLR3 $(83,84)$. TIRAP functions to recruit MyD88 leading to activation of MyD88-dependent pathway downstream of TLR2 and TLR4 $(85,86)$.Sterile- $\alpha$ - and armadillo-motif-containing protein 1 (SARM1), was shown to inhibit TRIF and is also critical for TLR-independent innate immunity (87). Thus, signaling pathways can be broadly classified as either MyD88-dependent pathway or TRIF-dependent pathway.

Hornung et al. have showed differential expression of TLR110 on human APCs and lymphocytes including T cells and their functional discrepancy in recognition of specific TLR ligands (88). $\mathrm{CD}^{+} \mathrm{T}$ cells express almost all TLRs at mRNA levels but may not express all as functional protein $(89,90)$. Moreover, they do not respond to all TLR ligands. Stimulation with TLR5, 7, or 8 agonists combined with TCR activation of $\mathrm{CD}^{+} \mathrm{T}$ cells resulted in increased proliferation and production of IL-2, IL-8, IL-10, IFN- $\gamma$ and TNF $\alpha$ (91). There are other reports as well suggesting the functional modulation of subtypes of $\mathrm{CD} 4^{+} \mathrm{T}$ cells by TLR ligands. The mouse Th1 but not Th2 cells responded to TLR2 agonist and resulted in enhanced proliferation and IFN- $\gamma$ production independent of TCR stimulation (92). This work validated that the TLR can regulate function of $\mathrm{CD} 4^{+} \mathrm{T}$ cells even in absence of TCR engagement. $\mathrm{CD} 4{ }^{+} \mathrm{CD} 25^{+}$regulatory T cells (Tregs) express majority of TLRs with selectively higher expression of TLR2, 4, 5, 7/8, and 10 compared to $\mathrm{CD} 4^{+} \mathrm{CD} 25^{-}$conventional T cells (93). Liu et al. showed that $\mathrm{CD} 4^{+} \mathrm{CD} 25^{+}$regulatory $\mathrm{T}$ cells and $\mathrm{CD} 4{ }^{+} \mathrm{CD} 25^{-}$conventional T cells express TLR2 and proliferated upon stimulation with its agonist. TLR2 stimulation also led to transient loss of Treg suppressive potential through suppression of FOXP3 $(94,95)$. However, Tregs also express TLR5 but upon stimulation with flagellin (ligand of TLR5), do not proliferate rather showed increased suppressive capacity and enhanced expression of FOXP3 (96). These reports suggest that the suppressive function of Treg can be either enhanced or dampened by the type of TLR ligand engaged. TLR2 stimulation not only abrogates suppressive functions of $\mathrm{CD}^{+}$Tregs but also drives naïve as well as effector Treg population toward IL17 producing Th17 phenotype (97). Th17 cells express TLR2 along with TLR6 compared to Th1 and Th2 subsets and promote Th17 differentiation upon Pam3Cys stimulation and accelerates experimental autoimmune encephalomyelitis (98). Like TLR2, TLR4 also regulate the functions of $\mathrm{CD} 4^{+} \mathrm{T}$ cells. In a mouse model of arthritis, mice lacking TLR2 showed enhanced histopathological scores of arthritis by a shift in $\mathrm{T}$ cell balance from Th2 and $\mathrm{T}$ regulatory cells toward pathogenic Th1 cells. TLR4, in contrast, contributes to more severe disease by modulating the Th17 cell population and IL-17 production $(99,100)$. Recently, Li et al. showed that high-mobility group box 1 (HMGB1) proteins decrease Treg/Th17 ratio by inhibiting FOXP3 and enhancing ROR $\gamma \mathrm{t}$ in $\mathrm{CD} 4^{+} \mathrm{T}$ cells via TLR4-IL6 axis in patients with chronic hepatitis B infections (101). This shows that HMGB1 (TLR4 ligand) act as a modulator of $\mathrm{CD}^{+} \mathrm{T}$ cells responses in chronic viral inflammation. $\mathrm{CD} 4^{+} \mathrm{T}$ cells also express intracellular TLRs such as TLR9 and TLR3. Both these TLRs promote $\mathrm{T}$ cell survival via activation of NF- $\mathrm{\kappa B}$ and MAPK signaling (102). Although the effector functions of $\mathrm{CD}^{+} \mathrm{T}$ cells are regulated by TLRs but the molecular pathway involved in skewing of $\mathrm{CD}^{+} \mathrm{T}$ cell function is poorly understood.

Like $\mathrm{CD} 4^{+} \mathrm{T}$ cells, $\mathrm{CD} 8^{+} \mathrm{T}$ cells also show differential expression of TLRs with high expression of TLR3 but lower expression of TRL1,2,5,9,10 compared to CD4 ${ }^{+} \mathrm{T}$ cells at mRNA level. It is important to note that the expression of TLR2, TLR3 and TLR5 increases on CD8 $\mathrm{T}$ cells in infected tonsils compared to controls (89) indicating immune activating role of TLRs in infections. Stimulation of $\mathrm{CD}^{+} \mathrm{T}$ cells through TLR2 agonists enhances their proliferation and IFN- $\gamma$ production $(103,104)$. It also promotes cytolytic activity of $\mathrm{CD} 8^{+} \mathrm{T}$ cells and enhances anti-tumor response mediated through MyD88-dependent TLR1/2 pathway (105). Recently, Mercier et al. showed that TLR2 cooperate with NOD-containing protein 1 (NOD1) to enhance TCR mediated activation and can serve as alternative co-stimulatory receptor in $\mathrm{CD}^{+} \mathrm{T}$ cells $(106)$. CD8 ${ }^{+} \mathrm{T}$ cells also express intracellular TLRs such as TLR3, TLR9 which are more potent in inducing $\mathrm{CD}^{+} \mathrm{T}$ cell activation in vivo (107).

Natural killer (NK) cell is a vital player in innate immune system. They recognize infected and transformed cells with downregulated major histocompatibility complex (MHC) class 1 molecules. They are the primary producers of IFN- $\gamma$ and are protective against infections. Unlike CD4 and CD8 T cells NK cells as well as $\mathrm{CD}_{56}{ }^{+} \mathrm{CD}^{+}{ }^{+}$NKT cells constitutively express TLR $1-8$ with high expression of TLR2 and 3 at mRNA level. They recognize 
bacterial PAMPs and respond by producing $\alpha$-defensins (108111). Human NK cells can also directly recognize Mycobacterium bovis via TLR2 and enhance their cytolytic activity against tumor cells (112). Tumor-associated macrophages induce NK cell IFN- $\gamma$ production and cytolytic activity upon TLR engagement (113). TLRs modulate NK cell function directly or indirectly to promote antibody dependent cell mediated cytotoxicity and cross presentation of viral antigens to T lymphocytes $(114,115)$. This highlights that the cells of adaptive immune system do express TLRs and their function can be directly or indirectly modulated by TLR ligands.

\section{ACTIVATION OF $\gamma \delta$ T CELLS BY TLR LIGANDS}

In 1997, the first human homolog of Drosophila Toll protein was cloned and characterized. It was also established that $\gamma \delta \mathrm{T}$ cells also express hToll mRNA (67). Purified $\gamma \delta$ T cells were found to respond to the E. coli native lipid A in a TCR-independent fashion and the LPS/lipid A-reactive $\gamma \delta$ T cells strongly expressed TLR2 mRNA. TLR2 antisense oligonucleotide inhibited the proliferation of $\gamma \delta \mathrm{T}$ cells in response to the native lipid A as well as the TLR2-deficient mice showed an impaired response of the $\gamma \delta \mathrm{T}$ cells following injection of native lipid A. These results suggest that TLR2 is involved in the activation of canonical $\mathrm{V} \gamma 6 / \mathrm{V} \delta 1 \mathrm{~T}$ cells by native lipid A (116). Again, functional presence of TLR2 on $\mathrm{V} \gamma 2 \mathrm{~V} \delta 2 \mathrm{~T}$ cells (also known as $\mathrm{V} \gamma 9 \mathrm{~V} \delta 2 \mathrm{~T}$ cells) was reported when the dual stimulation of $\mathrm{V} \gamma 2 \mathrm{~V} \delta 2 \mathrm{~T}$ cells with anti-TCR antibody and $\mathrm{Pam}_{3} \mathrm{Cys}$ increased synthesis and secretion of IFN- $\gamma$ and elevated the levels of CD107a expression. IFN- $\gamma$ secretion and cell surface CD107a levels are markers of increased effector function in $\mathrm{V} \gamma 2 \mathrm{~V} \delta 2 \mathrm{~T}$ cells (117). Similarly, Bruno et al. reported that IL-23 and TLR2 co-stimulation induces IL17 expression in $\gamma \delta \mathrm{T}$ cells. However, TLR1 and TLR2 expression was found only on CCR6 $^{+}$IL-17 producing murine peritoneal $\gamma \delta$ T cells but not others. Thus, $\gamma \delta$ T cells with innate receptor expression coupled with IL-17 production establishes them as first line of defense that can orchestrate an inflammatory response to pathogen-derived and environmental signals long before Th17 can sense the bacterial invasion (118). Pam3CSK4, TLR2 agonist was able to stimulate only splenic $\gamma \delta \mathrm{T}$ cell proliferation but not the dermal $\gamma \delta \mathrm{T}$ cells demonstrating that TLR2 signaling shows tissue tropism. (19). Furthermore, a profound change in the circulating $\gamma \delta$ T-cell population was observed in early burn injury $(24 \mathrm{~h})$. These $\gamma \delta \mathrm{T}$-cells showed TLR2 and TLR4 expression, priming them for TLR reactivity, However TLR expression was specific to circulatory $\gamma \delta \mathrm{T}$ cell subset and was transient, since it was not observed after postinjury ( 7 days). Transient nature of the post-burn increase in $\gamma \delta$ T-cell TLR expression is likely to be protective to the host, most likely via regulation of inflammation and initiation of healing processes (119). Mitochondrial danger-associated molecular patterns (MTDs) induce TLR2 and TLR4 expression on $\gamma \delta$ T cells in dose dependent manner. MTDs also induced the production of IL$1 \beta$, IL-6, IL-10, RANTES, and vascular endothelial growth factor by $\gamma \delta \mathrm{T}$-cells thereby resulting in initiation of sterile inflammation leading to tissue/cellular repair (120).

Different studies have reported that $\gamma \delta \mathrm{T}$ cells express TLR3 (121, 122). TLR3 recognizes viral dsRNA, synthetic analogs of dsRNA, polyinosinic-polycytidylic acid [poly (I:C)] and small interfering (si) RNA. The direct stimulation of freshly isolated $\gamma \delta$
T cells via TCR and surrogate TLR3 ligand poly (I:C) dramatically increased IFN- $\gamma$ production. Addition of neutralizing anti-TLR3 $\mathrm{mAb}$ inhibited the co-stimulatory effect of poly (I:C), presumably by antagonizing the TLR3 signaling (122). Thus, the integrated signals of TLR3 and TCR induce a strong antiviral effector function in $\gamma \delta$ T cells supporting the decisive role of $\gamma \delta$ T cells in early defense against viral infection. In other study, it has been reported that $\gamma \delta$ cells of term babies and of adults express TLR3 and TLR7 while the preterm babies have reduced levels. The greater levels of IFN- $\gamma$ protein was observed in adult and cord blood cells costimulated with anti-CD3 and poly(I:C) whereas this was not seen in $\gamma \delta \mathrm{T}$ cell clones of preterm babies. Thus, reduced level of TLR3 expression by preterm-derived clones had an overt functional consequence on IFN- $\gamma$ levels (11). Interestingly, a primary role of TLR3 in humans appears to mediate resistance to HSV-induced encephalitis (123). Hence, premature babies are particularly susceptible to HSV infection because of reduced levels of TLR3 on $\gamma \delta$ T cells.

TLR4 was reported to be absent in the $\gamma \delta$ T cells but can become functional in $\gamma \delta$ T cells depending on localization, environmental signals, or $\gamma \delta$ TCR usage $(19,118,124)$. However, our own data has shown that TLR4 is expressed on human $\gamma \delta$ T cells. Stimulation of $\gamma \delta$ T cells with LPS (TLR4 ligand) increased their proliferation, IFN- $\gamma$ release, and cytotoxic potential (125). DETCs lack cell surface expression of TLR4-MD2. MD-2 physically associates with TLR4 on the cell surface and is required for LPS signaling. However, TLR4-MD2 expression was upregulated when DETCs emigrated from the epidermis during cutaneous inflammation. The migration signals of DETCs may promote the TLR4-MD2 expression (126). Cairns et al. showed that late post-burn injury increased expression of TLR-4 on splenic T-cells (127). However, Martin et al. reported transient TLR- 4 expression post-burn in the circulation or spleen but were specific for the $\gamma \delta$ T-cell subset (119). Several evidences suggest that murine $\gamma \delta$ T cells recognize LPS/LA through TLR2 or TLR4 $(128,129)$. Importantly activated $\gamma \delta \mathrm{T}$ cells, especially V $\delta 2 \mathrm{~T}$ cells, in peripheral blood cells recognize LA, a major component of LPS, via TLR4 resulting in extensive proliferation and production of IFN- $\gamma$ and TNF- $\alpha$ in vitro (130). The data suggest that $\gamma \delta$ T cells play an important role in the control of infection induced by gram negative bacteria. Reynolds et al. showed that a heterogeneous population of $\gamma \delta$ T cells responds to LPS via TLR4 dependent manner and demonstrate the crucial and innate role of TLR 4 in promoting the activation of $\gamma \delta$ T cells, which contributes to the initiation of autoimmune inflammation (100). Another study showed the indirect role of TLR4 in HMGB-TLR4IL-23-IL17A axis between macrophages and $\gamma \delta \mathrm{T}$ cells, which contribute to the accumulation of neutrophils and liver inflammation. Necrotic hepatocytes release HMGB1, a damage-associated molecule or TLR4 ligand, which increased IL-23 production of macrophages in a TLR4 dependent manner. IL-23 aids $\gamma \delta \mathrm{T}$ cells in liver in the generation of IL-17A, which then recruits hepatic neutrophils (131).

Human $\gamma \delta \mathrm{T}$ cells were found to express appreciable levels of TLR7. Costimulation with poly I:C upregulated the TLR7 expression in TCR-cross linked freshly isolated $\gamma \delta$ T cells (124). In addition, tumor-infiltrating $\gamma \delta \mathrm{T}$ cells also express TLR7 (132). In case of mouse dermal $\gamma \delta \mathrm{T}$ cells, both TLR7 and 
TLR9 signaling promoted IL-17 production, which could be synergistically enhanced with the addition of IL-23 (19).

The identification of dominant $\gamma \delta \mathrm{T}$ cells in the total population of tumor-infiltrating lymphocytes (TILs) in renal, breast, and prostate cancer suggested that these cells might have the potent negative immune regulatory function $(132,133)$. The breast tumor-derived bulk $\gamma \delta$ T cell lines and clones efficiently suppressed the proliferation and IL-2 secretion of naïve/effector T cells and inhibited DC maturation and function. Hence, their depletion or the reversal of their suppressive function could enhance antitumor immune responses against breast cancer. Indeed as in $\mathrm{CD}^{+}$ regulatory T cells (Tregs), the immunosuppressive activity of $\gamma \delta \mathrm{T}$ cells could be reversed by human TLR8 ligands both in vitro and in vivo. Study revealed that MyD88, TRAF6, IKK $\alpha, \mathrm{IKK} \beta$ and $\mathrm{p} 38 \alpha$ molecules in $\gamma \delta 1$ cells were required for these cells to respond to TLR8 ligands $(132,134,135)$. Table 2 shows expression and co-stimulatory effects mediated by TLR activation of $\gamma \delta$ T cells

\section{TLRS MODULATE CROSSTALK BETWEEN $\gamma \delta$ T AND DENDRITIC CELLS}

The functional fate of effector $\mathrm{T}$ cells is governed by antigen presentation and the cytokine milieu in the local environment. Dendritic cells (DCs) being professional APCs, recognize the danger signal, process it, and present it to the T lymphocytes thereby modulate adaptive immune response. $\gamma \delta$ T cells influence the antigen presenting property of DCs. DCs pre-incubated with activated $\gamma \delta \mathrm{T}$ cells enhance the production of IFN- $\gamma$ by alloreactive $\mathrm{T}$ cells in mixed lymphocyte reaction (136). Moreover, $\gamma \delta \mathrm{T}$ cells not only upregulated CD86 and MHC I expression on DC but themselves get activated, leading to up-regulation of CD25, CD69, and cytokine production (137). These studies showed how $\gamma \delta \mathrm{T}$ cell and DCs regulate each other's function. There are reports, which have shown how $\gamma \delta \mathrm{T}$ cells interact with DC or vice versa via TLR ligands. Leslie et al. reported that stimulation with TLR ligands in $\gamma \delta / D C$ cocultures enhanced the maturation and production of IL12p70 by DCs (138). TLR also regulate the $\gamma \delta \mathrm{T}$ cells and DC crosstalk in microbial context. TLR2-stimulated DCs enhanced IFN- $\gamma$ production by V $\delta 2 \mathrm{~T}$ cells; conversely, phosphoantigen activated V $82 \mathrm{~T}$ cells enhanced TLR2-induced DC maturation via IFN- $\gamma$, which co-stimulated interleukin-12 (IL-12) p70 secretion by DCs (139). Further, $\gamma \delta$ T cells stimulated with TLR7 (CL097) or TLR3 (poly I: C) agonists produce IFN- $\gamma, \mathrm{TNF} \alpha$ and/or IL-6 thereby inducing DC maturation, which prime effector T cells against West Nile Virus (WNV) infection (140). This study confirmed that the antiviral effector immunity may be regulated by interplay of DCs, $\gamma \delta$ T cells and TLRs. Similarly, in human's $\gamma \delta \mathrm{T}$ cells and DCs regulate each other's immunostimulatory functions. TLR3 and TLR4 ligands stimulation of human PBMCs induced a rapid and exclusive IFN- $\gamma$ production by $\mathrm{V} \gamma 9 \mathrm{~V} \delta 2$ subset dependent on type 1 IFN secreted by monocytic DC. TLR-induced IFN- $\gamma$ response of $\mathrm{V} \gamma 9 \mathrm{~V} \delta 2 \mathrm{~T}$ cells led to efficient DC polarization into IL12 p70-producing cells (58). In another study, it was reported that V $\delta 2$ cells are indirectly activated by BCG and IL-12p70 secreted by DCs. IL-12p70 production by DC is modulated by Toll like receptor $2 / 4$ ligands from BCG and IFN- $\gamma$ secreted by memory CD4 T cells (141). This study portrayed the complex interplay between cells of the innate and adaptive immune response in contributing to immunosurveillance against pathogenic infections.

\section{TLRS COMPLEMENT CYTOTOXIC POTENTIAL OF $\gamma \delta$ T CELLS AGAINST TUMOR CELLS}

$\gamma \delta \mathrm{T}$ cells have capability to lyse different types of tumors and tumor-derived cell lines $(49,50,142-145)$. Circulating as well as tumor-infiltrating $\gamma \delta \mathrm{T}$ cells have the ability to produce abundant proinflammatory cytokines like IFN- $\gamma$ and TNF- $\alpha$, cytotoxic mediators and $\mathrm{MHC}$-independent recognition of antigens, render them as important players in cancer immunotherapy (143, 145). In addition to TCR, $\gamma \delta \mathrm{T}$ cells use additional stimulatory co-receptors or ligands including TLRs to execute effector functions and TLR agonists are considered as adjuvants in clinical trial of cancer immunotherapy (146). Kalyan et al. even quoted that "TLR signaling may perfectly complement the anti-tumor synergy of aminobisphosponates and activated $\gamma \delta \mathrm{T}$ cells and this combined innate artillery could provide the necessary ammunition to topple malignancy's stronghold on the immune system" (147). Paradoxically, TLR agonists execute dual role of enhancing immune response (148) as well as increasing invasiveness of tumor cells (149-152). Hence, the tripartite cooperation of tumor cell, TLRs, and $\gamma \delta \mathrm{T}$ cells should be carefully analyzed. In concordance to this, Shojaei et al. reported that Toll like receptor 3 and 7 agonists enhanced the tumor cell lysis by human $\gamma \delta \mathrm{T}$ cells. The enhanced capability of $\gamma \delta$ T cells to lyse tumor cells was attributed to increased expression of CD54 and downregulation of MHC class 1 on tumor cells. Poly(I:C) treatment of pancreatic adenocarcinomas resulted in overexpression of CD54 and concomitant coculture of tumor cells with $\gamma \delta$ T cells led to interaction between CD54 and its ligand CD11a/CD18 triggering effector function in $\gamma \delta$ T cells. However, TLR7 surrogate ligand induced

\section{Table 2 | Expression and functions mediated by TLRs on $\gamma \delta$ T cells}

\begin{tabular}{|c|c|c|}
\hline TLR & Functions & References \\
\hline TLR 2 & $\begin{array}{l}\text { Recognize LPS, enhance proliferation, induce IFN } \gamma \text { and CD107a expression, enhance IL17 secretion, } \\
\text { expression transiently increases after burn injury, mitochondrial danger-associated molecular patterns } \\
\text { (MTDs) induce expression and production of IL-1 } \beta, \text { IL-6, IL-10, RANTES, and VEGF }\end{array}$ & $(19,116-120)$ \\
\hline TLR3 & Induce IFN $\gamma$ production in conjunction with TCR stimulation, resistance to HSV induced encephalitis & $(11,121-123)$ \\
\hline TLR4 & Increases proliferation, IFN- $\gamma$ release, and cytotoxic potential, activation following burn injury & $(100,125,127,130)$ \\
\hline TLR7/9 & Upregulate upon poly I:C costimulation, promote IL-17 production & $(19,124,132)$ \\
\hline TLR8 & Reversal of immunosuppressive activity & $(132,134,135)$ \\
\hline
\end{tabular}


downregulation of MHC class 1 molecule on tumor cells resulting in a reduced affinity for inhibitory receptor NKG2A on $\gamma \delta \mathrm{T}$ cells (59). Manipulation of TLR signaling by using TLR8 agonists reversed the suppressive potential of $\gamma \delta$ Tregs found elevated in breast cancer (132). Polysaccharide K (PSK) known for its antitumor and immuno-modulatory function can also activate TLR2 leading to increased secretion of IFN- $\gamma$ by $\gamma \delta$ T cells on stimulation. The cell-cell contact between $\gamma \delta \mathrm{T}$ cells and DC was required for optimal activation of $\gamma \delta$ T cells. However, PSK along with antiTCR could co-activate $\gamma \delta$ T cells even in the absence of DC. The study confirmed that the anti-tumor effect of PSK was through activation of $\gamma \delta$ T cells (153).

Studies from our lab have shown that the TLR signaling in $\gamma \delta \mathrm{T}$ cells derived from the oral cancer (OC) patients may be dysfunctional. We reported that $\gamma \delta \mathrm{T}$ cells from healthy individuals (HI) and OC patients express higher levels of TLR2, TLR3, TLR4, and TLR9 than in $\alpha \beta$ T cells. Higher TLR expression was observed in HI compared to OC patients. Stimulation with IL2 and TLR agonists (Pam3CSK, Poly I:C, LPS, and CpG ODN) resulted in higher proliferative response of peripheral blood lymphocytes from $\mathrm{HI}$ compared to OC patients. However, the role of other immune cells that may influence the TLR ligand stimulation induced activation status of lymphocytes cannot be ignored (125). Impairment in TLR expression/signaling can be viewed as a strategy employed by tumor cells to avoid immune recognition.

\section{TLRs AND $\gamma \delta$ T CELLS IN DISEASES}

Studies have demonstrated the protective role of $\gamma \delta \mathrm{T}$ cells in infection and inflammation (154-157). Inoue et al. showed that during mycobacterial infection, $\gamma \delta \mathrm{T}$ cells precedes the $\alpha \beta \mathrm{T}$ cells, indicating role of $\gamma \delta \mathrm{T}$ cells as first line of defense against infections (158). The conserved molecular patterns associated with pathogens are directly recognized by $\gamma \delta \mathrm{T}$ cells leading to rapid protective response against the danger signal. Unlike $\alpha \beta$ TCR, $\gamma \delta$ TCR acts as pattern recognition receptor providing advantage in anti-infection immunity by directly initiating cytotoxicity against infected cells or through production of cytokine to involve multiple immune system components to combat infection $(159,160)$. Activated $\gamma \delta$ T cells through TLR3 and TLR4 ligands rescue the repressed maturation of virus-infected DCs and mount a potent antiviral response $(58,140)$. Malarial infection in MyD88 deficient mice resulted in impairment in $\mathrm{CD}^{-} 7^{-} \mathrm{IL}-17 \mathrm{~A}$-producing $\gamma \delta \mathrm{T}$ cell without affecting the IFN- $\gamma$ producing $\gamma \delta \mathrm{T}$ cells (161). This study specifies the role of TLR in promoting proliferation

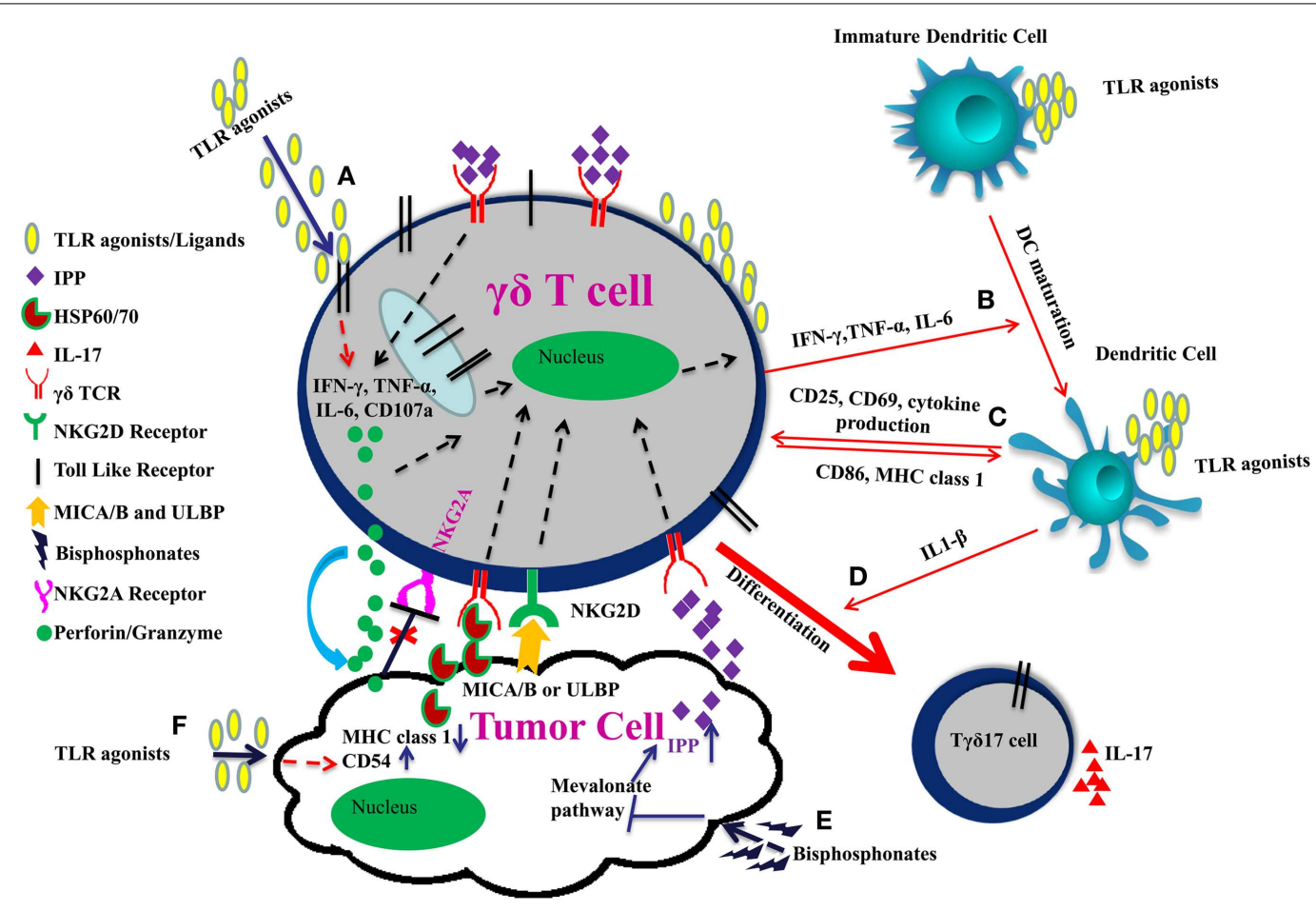

FIGURE 1 | Improving $\gamma \delta$ T cell functions by TLRs in combinatorial therapy. (A) TLR agonists induce effector function of $\gamma \delta$ T cells through IFN- $\gamma$, TNF- $\alpha$, IL-6 secretion, and increased expression of CD107a.

(B) IFN- $\gamma$, TNF- $\alpha$, and IL-6 secreted by $\gamma \delta$ T cells and TLR agonists promote the maturation of dendritic cell. (C) $\gamma \delta$ T cells upregulate CD 86 and $\mathrm{MHC}$ I expression on DCs and are themselves activated through up-regulation of CD25, CD69, and cytokine production thereby modulating each other's function. (D) Co-stimulation of $\gamma \delta$ T cells with TLR agonists and IL-1 $\beta$ secreted by dendritic cells promote their polarization toward IL17 producing cells. (E) $\gamma \delta$ TCR also recognizes the specific molecular patterns such as IPP, which are induced upon inhibition of mevalonate pathway by bisphosphonates. Moreover, NKG2D receptor on $\gamma \delta$ T cells recognizes MICA/B or ULBP expressed on tumor cells. This binding enhances release of perforins and granzymes by the $\gamma \delta \mathrm{T}$ cells leading to tumor cell lysis. (F) TLR agonists act as adjuvants and can induce CD54 expression and downregulation of MHC class 1 on tumor cells. Interaction between CD54 and its ligand CD11a/CD18 trigger effector functions in $\gamma \delta$ T cells. Downregulation of $\mathrm{MHC}$ class 1 molecule on tumor cells result in reduced signaling through the inhibitory receptor NKG2A on $\gamma \delta$ T cells, which enhances the cytotoxic potential of $\gamma \delta \mathrm{T}$ cell. 
of proinflammatory $\gamma \delta \mathrm{T}$ cells. Another study by Martin et al. showed that IL17 producing $\gamma \delta$ T cells express TLR1 and TLR2 and expand in response to their ligands and mount an adequate response against heat-killed $M$. tuberculosis or C. albicans infection (118). However, $\gamma \delta \mathrm{T}$ cell are also known to directly recognize the pathogen-derived molecules and mediate cytotoxic effector function either through secretion of perforin and granzyme B or by secretion of proinflammatory cytokine IL17 (162-164). The involvement of TLRs in regulating anti-microbial $\gamma \delta \mathrm{T}$ cell function should be investigated in depth to exploit it as a cell based therapy for infectious diseases.

\section{CONCLUDING REMARKS}

The characteristic copious IFN- $\gamma$ or IL17 secretion, MHCindependent antigen recognition, tissue tropism, and potent cytotoxicity make $\gamma \delta \mathrm{T}$ cells promising targets for immunotherapy. Similar to $\alpha \beta$ T cells, $\gamma \delta$ T cells exhibit functional and phenotypic plasticity, which influences the nature of the downstream adaptive immune response. The adoptive transfer of ex vivo expanded $\mathrm{V} \gamma 9 \mathrm{~V} \delta 2 \mathrm{~T}$ cells or in vivo activation of $\mathrm{V} \gamma 9 \mathrm{~V} \delta 2 \mathrm{~T}$ cells (phosphoantigens or amino-bisphosphonates) can be utilized as adjuvant to conventional therapies. Clinical trials of $\mathrm{V} \gamma 9 \mathrm{~V} \delta 2 \mathrm{~T}$ cells as immunotherapeutic agents have shown encouraging results that could be attributed to its low toxicity grade. Combinations of cellular immune-based therapies with chemotherapy and other anti-tumor agents may be of clinical benefit in the treatment of malignancies. Combinatorial treatment using, chemotherapeutic agents or bisphosphonate zoledronate (ZOL) sensitizes tumorderived cell lines to rapid $\gamma \delta \mathrm{T}$ cells killing. $\mathrm{V} \gamma 9 \mathrm{~V} \delta 2 \mathrm{~T}$ cell triggering may be also enhanced by combining TCR stimulation with engagement of TLRs. Various TLR agonists are currently under investigation in clinical trials for their ability to orchestrate anti-tumor immunity. In one study, simultaneous use of both Imiquimod (TLR7 agonist) and CpG-ODN (TLR9 agonist) loaded onto virus like nanoparticles was found to be effective in triggering effector and memory $\mathrm{CD}^{+} \mathrm{T}$ cell response (165). Similarly, combination of $\gamma \delta \mathrm{T}$ cells and DCs along with nanoparticle loaded TLR agonists can be employed for developing effective immunotherapeutic strategies. The direct or indirect stimulation of $\gamma \delta$ T cells by TLR agonists could be a strategy to optimize Th1-mediated immune responses as adjuvant in vaccines against infectious or malignant diseases.

Administration of an "immunogenic chemotherapy" (such as oxaliplatin or anthracycline or an X-ray-based regimen) or local delivery of TLR surrogates in the tumor microenvironment (which stimulate local DCs and provides a source of IL-1 $\beta$ ) may be also instrumental in polarization of $\gamma \delta$ TILs into IL17 producing cells. $\mathrm{T} \gamma \delta 17$ cells play a crucial role in anti-microbial immunity but their role in tumor immunity remains controversial. $\mathrm{T} \gamma \delta 17$ have both pro and anti-tumor properties. TLR use in combinatorial therapy, therefore, could be a double edged sword. Careful use of TLR agonists in combinatorial $\gamma \delta \mathrm{T}$ cell based therapy is needed to strike the balance between pro and anti-tumor effects (Figure 1).

\section{REFERENCES}

1. Tipping PG. Toll-like receptors: the interface between innate and adaptive immunity. J Am Soc Nephrol (2006) 17(7):1769-71. doi:10.1681/ASN. 2006050489
2. Holtmeier W, Kabelitz D. Gammadelta T cells link innate and adaptive immune responses. Chem Immunol Allergy (2005) 86:151-83. doi:10.1159/000086659

3. Akira S, Takeda K, Kaisho T. Toll-like receptors: critical proteins linking innate and acquired immunity. Nat Immunol (2001) 2(8):675-80. doi:10.1038/90609

4. Bonneville M, O’Brien RL, Born WK. Gammadelta T cell effector functions: a blend of innate programming and acquired plasticity. Nat Rev Immunol (2010) 10(7):467-78. doi:10.1038/nri2781

5. Hayday AC. Gammadelta T cells and the lymphoid stress-surveillance response. Immunity (2009) 31(2):184-96. doi:10.1016/j.immuni.2009.08.006

6. Wesch D, Peters C, Oberg HH, Pietschmann K, Kabelitz D. Modulation of gammadelta $\mathrm{T}$ cell responses by TLR ligands. Cell Mol Life Sci (2011) 68(14):2357-70. doi:10.1007/s00018-011-0699-1

7. Hayday AC. [Gamma][delta] cells: a right time and a right place for a conserved third way of protection. Annu Rev Immunol (2000) 18:975-1026. doi:10.1146/annurev.immunol.18.1.975

8. Starr TK, Jameson SC, Hogquist KA. Positive and negative selection of T cells. Annu Rev Immunol (2003) 21:139-76. doi:10.1146/annurev.immunol. 21.120601.141107

9. Velilla PA, Rugeles MT, Chougnet CA. Defective antigen-presenting cell function in human neonates. Clin Immunol (2006) 121(3):251-9. doi:10.1016/j. clim.2006.08.010

10. De Rosa SC, Andrus JP, Perfetto SP, Mantovani JJ, Herzenberg LA, Herzenberg LA, et al. Ontogeny of gamma delta T cells in humans. J Immunol (2004) 172(3):1637-45. doi:10.4049/jimmunol.172.3.1637

11. Gibbons DL, Haque SF, Silberzahn T, Hamilton K, Langford C, Ellis P, et al. Neonates harbour highly active gammadelta $\mathrm{T}$ cells with selective impairments in preterm infants. Eur J Immunol (2009) 39(7):1794-806. doi:10.1002/eji. 200939222

12. Shin S, El-Diwany R, Schaffert S, Adams EJ, Garcia KC, Pereira P, et al. Antigen recognition determinants of gammadelta $\mathrm{T}$ cell receptors. Science (2005) 308(5719):252-5. doi:10.1126/science.1106480

13. Kalyan S, Kabelitz D. Defining the nature of human gammadelta T cells: a biographical sketch of the highly empathetic. Cell Mol Immunol (2013) 10(1):21-9. doi:10.1038/cmi.2012.44

14. Li H, Lebedeva MI, Llera AS, Fields BA, Brenner MB, Mariuzza RA. Structure of the Vdelta domain of a human gammadelta T-cell antigen receptor. Nature (1998) 391(6666):502-6. doi:10.1038/35172

15. Vavassori S, Kumar A, Wan GS, Ramanjaneyulu GS, Cavallari M, El Daker S, et al. Butyrophilin 3A1 binds phosphorylated antigens and stimulates human gammadelta T cells. Nat Immunol (2013) 14(9):908-16. doi:10.1038/ni.2665

16. Bordessoule D, Gaulard P, Mason DY. Preferential localisation of human lymphocytes bearing gamma delta $\mathrm{T}$ cell receptors to the red pulp of the spleen. J Clin Pathol (1990) 43(6):461-4. doi:10.1136/jcp.43.6.461

17. Itohara S, Farr AG, Lafaille JJ, Bonneville M, Takagaki Y, Haas W, et al. Homing of a gamma delta thymocyte subset with homogeneous T-cell receptors to mucosal epithelia. Nature (1990) 343(6260):754-7. doi:10.1038/343754a0

18. Goodman T, Lefrancois L. Intraepithelial lymphocytes. Anatomical site, not $\mathrm{T}$ cell receptor form, dictates phenotype and function. J Exp Med (1989) 170(5):1569-81. doi:10.1084/jem.170.5.1569

19. Cai Y, Shen X, Ding C, Qi C, Li K, Li X, et al. Pivotal role of dermal IL17-producing gammadelta $\mathrm{T}$ cells in skin inflammation. Immunity (2011) 35(4):596-610. doi:10.1016/j.immuni.2011.08.001

20. Gray EE, Suzuki K, Cyster JG. Cutting edge: identification of a motile IL-17producing gammadelta $\mathrm{T}$ cell population in the dermis. J Immunol (2011) 186(11):6091-5. doi:10.4049/jimmunol.1100427

21. Havran WL, Allison JP. Origin of Thy-1+ dendritic epidermal cells of adult mice from fetal thymic precursors. Nature (1990) 344(6261):68-70. doi:10. 1038/344068a0

22. Jameson J, Ugarte K, Chen N, Yachi P, Fuchs E, Boismenu R, et al. A role for skin gammadelta $\mathrm{T}$ cells in wound repair. Science (2002) 296(5568):747-9. doi:10.1126/science.1069639

23. Sharp LL, Jameson JM, Cauvi G, Havran WL. Dendritic epidermal T cells regulate skin homeostasis through local production of insulin-like growth factor 1. Nat Immunol (2005) 6(1):73-9. doi:10.1038/ni1152

24. Chien YH, Jores R, Crowley MP. Recognition by gamma/delta T cells. Annu Rev Immunol (1996) 14:511-32. doi:10.1146/annurev.immunol.14.1.511

25. Adams EJ, Chien YH, Garcia KC. Structure of a gammadelta T cell receptor in complex with the nonclassical MHC T22. Science (2005) 308(5719):227-31. doi:10.1126/science. 1106885 
26. Bluestone JA, Cron RQ, Cotterman M, Houlden BA, Matis LA. Structure and specificity of $\mathrm{T}$ cell receptor gamma/delta on major histocompatibility complex antigen-specific CD3+, CD4-, CD8- T lymphocytes. J Exp Med (1988) 168(5):1899-916. doi:10.1084/jem.168.5.1899

27. Crowley MP, Reich Z, Mavaddat N, Altman JD, Chien Y. The recognition of the nonclassical major histocompatibility complex (MHC) class I molecule, T10, by the gammadelta T cell, G8. J Exp Med (1997) 185(7):1223-30. doi:10.1084/jem.185.7.1223

28. Bonneville M, Ito K, Krecko EG, Itohara S, Kappes D, Ishida I, et al. Recognition of a self major histocompatibility complex TL region product by gamma delta T-cell receptors. Proc Natl Acad Sci U S A (1989) 86(15):5928-32. doi:10.1073/pnas.86.15.5928

29. Matis LA, Fry AM, Cron RQ, Cotterman MM, Dick RF, Bluestone JA. Structure and specificity of a class II MHC alloreactive gamma delta T cell receptor heterodimer. Science (1989) 245(4919):746-9. doi:10.1126/science. 2528206

30. Schild H, Mavaddat N, Litzenberger C, Ehrich EW, Davis MM, Bluestone JA, et al. The nature of major histocompatibility complex recognition by gamma delta T cells. Cell (1994) 76(1):29-37. doi:10.1016/0092-8674(94)90170-8

31. Sciammas R, Kodukula P, Tang Q, Hendricks RL, Bluestone JA. T cell receptorgamma/delta cells protect mice from herpes simplex virus type 1-induced lethal encephalitis. J Exp Med (1997) 185(11):1969-75. doi:10.1084/jem.185.11.1969

32. Johnson RM, Lancki DW, Sperling AI, Dick RF, Spear PG, Fitch FW, et al. A murine CD4-, CD8- T cell receptor-gamma delta T lymphocyte clone specific for herpes simplex virus glycoprotein I. J Immunol (1992) 148(4): 983-8.

33. Zeng X, Wei YL, Huang J, Newell EW, Yu H, Kidd BA, et al. Gammadelta T cells recognize a microbial encoded $\mathrm{B}$ cell antigen to initiate a rapid antigenspecific interleukin-17 response. Immunity (2012) 37(3):524-34. doi:10.1016/ j.immuni.2012.06.011

34. Dieudé M, Striegl H, Tyznik AJ, Wang J, Behar SM, Piccirillo CA, et al. Cardiolipin binds to CD1d and stimulates CD1d-restricted gammadelta T cells in the normal murine repertoire. J Immunol (2011) 186(8):4771-81. doi:10.4049/jimmunol.1000921

35. Zhang L, Jin N, Nakayama M, O’Brien RL, Eisenbarth GS, Born WK. Gamma delta $\mathrm{T}$ cell receptors confer autonomous responsiveness to the insulin-peptide B:9-23. J Autoimmun (2010) 34(4):478-84. doi:10.1016/j.jaut.2009.12.008

36. Havran WL, Chien YH, Allison JP. Recognition of self antigens by skinderived T cells with invariant gamma delta antigen receptors. Science (1991) 252(5011):1430-2. doi:10.1126/science.1828619

37. Tanaka Y, Sano S, Nieves E, De Libero G, Rosa D, Modlin RL, et al. Nonpeptide ligands for human gamma delta T cells. Proc Natl Acad Sci U S A (1994) 91(17):8175-9. doi:10.1073/pnas.91.17.8175

38. Tanaka Y, Morita CT, Tanaka Y, Nieves E, Brenner MB, Bloom BR. Natural and synthetic non-peptide antigens recognized by human gamma delta $\mathrm{T}$ cells. Nature (1995) 375(6527):155-8. doi:10.1038/375155a0

39. Rust CJ, Verreck F, Vietor H, Koning F. Specific recognition of staphylococcal enterotoxin A by human $\mathrm{T}$ cells bearing receptors with the $\mathrm{V}$ gamma 9 region. Nature (1990) 346(6284):572-4. doi:10.1038/346572a0

40. Willcox CR, Pitard V, Netzer S, Couzi L, Salim M, Silberzahn T, et al. Cytomegalovirus and tumor stress surveillance by binding of a human gammadelta $\mathrm{T}$ cell antigen receptor to endothelial protein C receptor. Nat Immunol (2012) 13(9):872-9. doi:10.1038/ni.2394

41. Scotet E, Martinez LO, Grant E, Barbaras R, Jenö P, Guiraud M, et al. Tumor recognition following Vgamma9Vdelta2 $\mathrm{T}$ cell receptor interactions with a surface F1-ATPase-related structure and apolipoprotein A-I. Immunity (2005) 22(1):71-80. doi:10.1016/j.immuni.2004.11.012

42. Russano AM, Agea E, Corazzi L, Postle AD, De Libero G, Porcelli S, et al. Recognition of pollen-derived phosphatidyl-ethanolamine by human CD1drestricted gamma delta T cells. J Allergy Clin Immunol (2006) 117(5):1178-84. doi:10.1016/j.jaci.2006.01.001

43. Bai L, Picard D, Anderson B, Chaudhary V, Luoma A, Jabri B, et al. The majority of CD1d-sulfatide-specific T cells in human blood use a semiinvariant Vdeltal TCR. Eur J Immunol (2012) 42(9):2505-10. doi:10.1002/eji.201242531

44. Uldrich AP, Le Nours J, Pellicci DG, Gherardin NA, McPherson KG, Lim RT, et al. CD1d-lipid antigen recognition by the gammadelta TCR. Nat Immunol (2013) 14(11):1137-45. doi:10.1038/ni.2713
45. Luoma AM, Castro CD, Mayassi T, Bembinster LA, Bai L, Picard D, et al. Crystal structure of Vdelta1 $\mathrm{T}$ cell receptor in complex with CD1d-sulfatide shows MHC-like recognition of a self-lipid by human gammadelta T cells. Immunity (2013) 39(6):1032-42. doi:10.1016/j.immuni.2013.11.001

46. Groh V, Steinle A, Bauer S, Spies T. Recognition of stress-induced MHC molecules by intestinal epithelial gammadelta $\mathrm{T}$ cells. Science (1998) 279(5357):1737-40. doi:10.1126/science.279.5357.1737

47. $\mathrm{Wu} J$, Groh V, Spies T. T cell antigen receptor engagement and specificity in the recognition of stress-inducible MHC class I-related chains by human epithelial gamma delta T cells. J Immunol (2002) 169(3):1236-40. doi:10.4049/jimmunol.169.3.1236

48. Kong Y, Cao W, Xi X, Ma C, Cui L, He W. The NKG2D ligand ULBP4 binds to TCRgamma9/delta2 and induces cytotoxicity to tumor cells through both TCRgammadelta and NKG2D. Blood (2009) 114(2):310-7. doi:10.1182/blood2008-12-196287

49. Laad AD, Thomas ML, Fakih AR, Chiplunkar SV. Human gamma delta $\mathrm{T}$ cells recognize heat shock protein-60 on oral tumor cells. Int J Cancer (1999) 80(5):709-14. doi:10.1002/(SICI)1097-0215(19990301)80:5<709: :AID-IJC14>3.0.CO;2-R

50. Thomas ML, Samant UC, Deshpande RK, Chiplunkar SV. Gammadelta T cells lyse autologous and allogenic oesophageal tumours: involvement of heatshock proteins in the tumour cell lysis. Cancer Immunol Immunother (2000) 48(11):653-9. doi:10.1007/s002620050014

51. Zhang H, Hu H, Jiang X, He H, Cui L, He W. Membrane HSP70: the molecule triggering gammadelta $\mathrm{T}$ cells in the early stage of tumorigenesis. Immunol Invest (2005) 34(4):453-68. doi:10.1080/08820130500265349

52. Hirsh MI, Hashiguchi N, Chen Y, Yip L, Junger WG. Surface expression of HSP72 by LPS-stimulated neutrophils facilitates gammadeltaT cell-mediated killing. Eur J Immunol (2006) 36(3):712-21. doi:10.1002/eji.200535422

53. Kotsiopriftis M, Tanner JE, Alfieri C. Heat shock protein 90 expression in Epstein-Barr virus-infected B cells promotes gammadelta T-cell proliferation in vitro. J Virol (2005) 79(11):7255-61. doi:10.1128/JVI.79.11.7255-7261.2005

54. Morita CT, Beckman EM, Bukowski JF, Tanaka Y, Band H, Bloom BR, et al. Direct presentation of nonpeptide prenyl pyrophosphate antigens to human gamma delta T cells. Immunity (1995) 3(4):495-507. doi:10.1016/ 1074-7613(95)90178-7

55. Gogoi D, Dar AA, Chiplunkar SV. Involvement of Notch in activation and effector functions of gammadelta T cells. J Immunol (2014) 192(5):2054-62. doi:10.4049/jimmunol.1300369

56. Rincon-Orozco B, Kunzmann V, Wrobel P, Kabelitz D, Steinle A, Herrmann T. Activation of $\mathrm{V}$ gamma $9 \mathrm{~V}$ delta $2 \mathrm{~T}$ cells by NKG2D. J Immunol (2005) 175(4):2144-51. doi:10.4049/jimmunol.175.4.2144

57. Nedellec S, Sabourin C, Bonneville M, Scotet E. NKG2D costimulates human $\mathrm{V}$ gamma $9 \mathrm{~V}$ delta $2 \mathrm{~T}$ cell antitumor cytotoxicity through protein kinase $\mathrm{C}$ theta-dependent modulation of early TCR-induced calcium and transduction signals. J Immunol (2010) 185(1):55-63. doi:10.4049/jimmunol. 1000373

58. Devilder MC, Allain S, Dousset C, Bonneville M, Scotet E. Early triggering of exclusive IFN-gamma responses of human Vgamma9Vdelta2 $\mathrm{T}$ cells by TLR-activated myeloid and plasmacytoid dendritic cells. J Immunol (2009) 183(6):3625-33. doi:10.4049/jimmunol.0901571

59. Shojaei H, Oberg HH, Juricke M, Marischen L, Kunz M, Mundhenke C, et al. Toll-like receptors 3 and 7 agonists enhance tumor cell lysis by human gammadelta T cells. Cancer Res (2009) 69(22):8710-7. doi:10.1158/0008-5472. CAN-09-1602

60. Janeway CA Jr, Medzhitov R. Innate immune recognition. Annu Rev Immunol (2002) 20:197-216. doi:10.1146/annurev.immunol.20.083001.084359

61. Mogensen TH. Pathogen recognition and inflammatory signaling in innate immune defenses. Clin Microbiol Rev (2009) 22(2):240-73. doi:10.1128/CMR. 00046-08

62. Janeway CA Jr. Approaching the asymptote? Evolution and revolution in immunology. Cold Spring Harb Symp Quant Biol (1989) 54(Pt 1):1-13. doi:10.1101/SQB.1989.054.01.003

63. Akira S, Uematsu S, Takeuchi O. Pathogen recognition and innate immunity. Cell (2006) 124(4):783-801. doi:10.1016/j.cell.2006.02.015

64. Beutler BA. TLRs and innate immunity. Blood (2009) 113(7):1399-407. doi:10.1182/blood-2008-07-019307 
65. Medzhitov R. Recognition of microorganisms and activation of the immune response. Nature (2007) 449(7164):819-26. doi:10.1038/nature06246

66. Pasare C, Medzhitov R. Toll-like receptors: linking innate and adaptive immunity. Microbes Infect (2004) 6(15):1382-7. doi:10.1016/j.micinf.2004.08.018

67. Medzhitov R, Preston-Hurlburt P, Janeway CA Jr. A human homologue of the Drosophila toll protein signals activation of adaptive immunity. Nature (1997) 388(6640):394-7. doi:10.1038/41131

68. Takeda K, Akira S. Toll-like receptors in innate immunity. Int Immunol (2005) 17(1):1-14. doi:10.1093/intimm/dxh186

69. Shi Z, Cai Z, Sanchez A, Zhang T, Wen S, Wang J, et al. A novel toll-like receptor that recognizes vesicular stomatitis virus. J Biol Chem (2011) 286(6):4517-24. doi:10.1074/jbc.M110.159590

70. Oldenburg M, Krüger A, Ferstl R, Kaufmann A, Nees G, Sigmund A, et al. TLR13 recognizes bacterial 23S rRNA devoid of erythromycin resistance-forming modification. Science (2012) 337(6098):1111-5. doi:10.1126/science.1220363

71. Koblansky AA, Jankovic D, Oh H, Hieny S, Sungnak W, Mathur R, et al. Recognition of profilin by toll-like receptor 12 is critical for host resistance to Toxoplasma gondii. Immunity (2013) 38(1):119-30. doi:10.1016/j.immuni. 2012.09.016

72. Rock FL, Hardiman G, Timans JC, Kastelein RA, Bazan JF. A family of human receptors structurally related to Drosophila toll. Proc Natl Acad Sci U S A (1998) 95(2):588-93. doi:10.1073/pnas.95.2.588

73. Poltorak A, He X, Smirnova I, Liu MY, Van Huffel C, Du X, et al. Defective LPS signaling in $\mathrm{C} 3 \mathrm{H} / \mathrm{HeJ}$ and $\mathrm{C} 57 \mathrm{BL} / 10 \mathrm{ScCr}$ mice: mutations in Tlr4 gene. Science (1998) 282(5396):2085-8. doi:10.1126/science.282.5396.2085

74. Tabeta K, Georgel P, Janssen E, Du X, Hoebe K, Crozat K, et al. Toll-like receptors 9 and 3 as essential components of innate immune defense against mouse cytomegalovirus infection. Proc Natl Acad Sci U S A (2004) 101(10):3516-21. doi:10.1073/pnas.0400525101

75. Brinkmann MM, Spooner E, Hoebe K, Beutler B, Ploegh HL, Kim YM. The interaction between the ER membrane protein UNC93B and TLR3, 7, and 9 is crucial for TLR signaling. J Cell Biol (2007) 177(2):265-75. doi:10.1083/jcb.200612056

76. Kim YM, Brinkmann MM, Paquet ME, Ploegh HL. UNC93B1 delivers nucleotide-sensing toll-like receptors to endolysosomes. Nature (2008) 452(7184):234-8. doi:10.1038/nature06726

77. Ewald SE, Lee BL, Lau L, Wickliffe KE, Shi GP, Chapman HA, et al. The ectodomain of toll-like receptor 9 is cleaved to generate a functional receptor. Nature (2008) 456(7222):658-62. doi:10.1038/nature07405

78. O'Neill LA, Golenbock D, Bowie AG. The history of toll-like receptors - redefining innate immunity. Nat Rev Immunol (2013) 13(6):453-60. doi:10.1038/ nri3446

79. Wesche H, Henzel WJ, Shillinglaw W, Li S, Cao Z. MyD88: an adapter that recruits IRAK to the IL-1 receptor complex. Immunity (1997) 7(6):837-47. doi:10.1016/S1074-7613(00)80402-1

80. Yamamoto M, Sato S, Mori K, Hoshino K, Takeuchi O, Takeda K, et al. Cutting edge: a novel toll/IL-1 receptor domain-containing adapter that preferentially activates the IFN-beta promoter in the toll-like receptor signaling. J Immunol (2002) 169(12):6668-72. doi:10.4049/jimmunol.169.12.6668

81. Oshiumi H, Matsumoto M, Funami K, Akazawa T, Seya T. TICAM-1, an adaptor molecule that participates in toll-like receptor 3-mediated interferon-beta induction. Nat Immunol (2003) 4(2):161-7. doi:10.1038/ni886

82. Yamamoto M, Sato S, Hemmi H, Hoshino K, Kaisho T, Sanjo H, et al. Role of adaptor TRIF in the MyD88-independent toll-like receptor signaling pathway. Science (2003) 301(5633):640-3. doi:10.1126/science.1087262

83. Fitzgerald KA, Rowe DC, Barnes BJ, Caffrey DR, Visintin A, Latz E, et al. LPSTLR4 signaling to IRF-3/7 and NF-kappaB involves the toll adapters TRAM and TRIF. J Exp Med (2003) 198(7):1043-55. doi:10.1084/jem.20031023

84. Yamamoto M, Sato S, Hemmi H, Uematsu S, Hoshino K, Kaisho T, et al. TRAM is specifically involved in the toll-like receptor 4-mediated MyD88independent signaling pathway. Nat Immunol (2003) 4(11):1144-50. doi:10. 1038/ni986

85. Fitzgerald KA, Palsson-McDermott EM, Bowie AG, Jefferies CA, Mansell AS, Brady G, et al. Mal (MyD88-adapter-like) is required for toll-like receptor-4 signal transduction. Nature (2001) 413(6851):78-83. doi:10.1038/ 35092578

86. Horng T, Barton GM, Medzhitov R. TIRAP: an adapter molecule in the toll signaling pathway. Nat Immunol (2001) 2(9):835-41. doi:10.1038/ni0901-835
87. Carty M, Goodbody R, Schröder M, Stack J, Moynagh PN, Bowie AG. The human adaptor SARM negatively regulates adaptor protein TRIF-dependent toll-like receptor signaling. Nat Immunol (2006) 7(10):1074-81. doi:10.1038/ nil382

88. Hornung V, Rothenfusser S, Britsch S, Krug A, Jahrsdörfer B, Giese T, et al. Quantitative expression of toll-like receptor 1-10 mRNA in cellular subsets of human peripheral blood mononuclear cells and sensitivity to CpG oligodeoxynucleotides. J Immunol (2002) 168(9):4531-7. doi:10.4049/ jimmunol.168.9.4531

89. Mansson A, Adner M, Cardell LO. Toll-like receptors in cellular subsets of human tonsil T cells: altered expression during recurrent tonsillitis. Respir Res (2006) 7:36. doi:10.1186/1465-9921-7-36

90. Kabelitz D. Expression and function of toll-like receptors in T lymphocytes. Curr Opin Immunol (2007) 19(1):39-45. doi:10.1016/j.coi.2006.11.007

91. Caron G, Duluc D, Frémaux I, Jeannin P, David C, Gascan H, et al. Direct stimulation of human T cells via TLR5 and TLR7/8: flagellin and R-848 up-regulate proliferation and IFN-gamma production by memory CD4+ T cells. J Immunol (2005) 175(3):1551-7. doi:10.4049/jimmunol.175.3.1551

92. Imanishi T, Hara H, Suzuki S, Suzuki N, Akira S, Saito T. Cutting edge: TLR2 directly triggers Th1 effector functions. J Immunol (2007) 178(11):6715-9. doi:10.4049/jimmunol.178.11.6715

93. Dai J, Liu B, Li Z. Regulatory T cells and toll-like receptors: what is the missing link? Int Immunopharmacol (2009) 9(5):528-33. doi:10.1016/j.intimp. 2009.01.027

94. Liu H, Komai-Koma M, Xu D, Liew FY. Toll-like receptor 2 signaling modulates the functions of CD4+ CD25+ regulatory T cells. Proc Natl Acad Sci U S A (2006) 103(18):7048-53. doi:10.1073/pnas.0601554103

95. Sutmuller RP, den Brok MH, Kramer M, Bennink EJ, Toonen LW, Kullberg BJ, et al. Toll-like receptor 2 controls expansion and function of regulatory $\mathrm{T}$ cells. J Clin Invest (2006) 116(2):485-94. doi:10.1172/JCI25439

96. Crellin NK, Garcia RV, Hadisfar O, Allan SE, Steiner TS, Levings MK. Human CD4+ $\mathrm{T}$ cells express TLR5 and its ligand flagellin enhances the suppressive capacity and expression of FOXP3 in CD4+CD25+ T regulatory cells. J Immunol (2005) 175(12):8051-9. doi:10.4049/jimmunol.175.12.8051

97. Nyirenda MH, Sanvito L, Darlington PJ, O’Brien K, Zhang GX, Constantinescu $\mathrm{CS}$, et al. TLR2 stimulation drives human naive and effector regulatory $\mathrm{T}$ cells into a Th17-like phenotype with reduced suppressive function. J Immunol (2011) 187(5):2278-90. doi:10.4049/jimmunol.1003715

98. Reynolds JM, Pappu BP, Peng J, Martinez GJ, Zhang Y, Chung Y, et al. Tolllike receptor 2 signaling in CD4(+) $\mathrm{T}$ lymphocytes promotes $\mathrm{T}$ helper 17 responses and regulates the pathogenesis of autoimmune disease. Immunity (2010) 32(5):692-702. doi:10.1016/j.immuni.2010.04.010

99. Abdollahi-Roodsaz S, Joosten LA, Koenders MI, Devesa I, Roelofs MF, Radstake TR, et al. Stimulation of TLR2 and TLR4 differentially skews the balance of T cells in a mouse model of arthritis. J Clin Invest (2008) 118(1):205-16. doi:10.1172/JCI32639

100. Reynolds JM, Martinez GJ, Chung Y, Dong C. Toll-like receptor 4 signaling in T cells promotes autoimmune inflammation. Proc Natl Acad Sci U S A (2012) 109(32):13064-9. doi:10.1073/pnas.1120585109

101. Li J, Wang FP, She WM, Yang CQ, Li L, Tu CT, et al. Enhanced highmobility group box 1 (HMGB1) modulates regulatory T cells (Treg)/T helper 17 (Th17) balance via toll-like receptor (TLR)-4-interleukin (IL)-6 pathway in patients with chronic hepatitis B. J Viral Hepat (2014) 21(2):129-40. doi:10.1111/jvh.12152

102. Reynolds JM, Dong C. Toll-like receptor regulation of effector T lymphocyte function. Trends Immunol (2013) 34(10):511-9. doi:10.1016/j.it.2013.06.003

103. Mercier BC, Cottalorda A, Coupet CA, Marvel J, Bonnefoy-Bérard N. TLR2 engagement on CD8 T cells enables generation of functional memory cells in response to a suboptimal TCR signal. J Immunol (2009) 182(4):1860-7. doi:10.4049/jimmunol.0801167

104. Cottalorda A, Mercier BC, Mbitikon-Kobo FM, Arpin C, Teoh DY, McMichael A, et al. TLR2 engagement on memory CD8(+) T cells improves their cytokinemediated proliferation and IFN-gamma secretion in the absence of Ag. Eur J Immunol (2009) 39(10):2673-81. doi:10.1002/eji.200939627

105. Asprodites N, Zheng L, Geng D, Velasco-Gonzalez C, Sanchez-Perez L, Davila E. Engagement of toll-like receptor-2 on cytotoxic T-lymphocytes occurs in vivo and augments antitumor activity. FASEB J (2008) 22(10):3628-37. doi:10.1096/fj.08-108274 
106. Mercier BC, Ventre E, Fogeron ML, Debaud AL, Tomkowiak M, Marvel J, et al. NOD1 cooperates with TLR2 to enhance T cell receptor-mediated activation in CD8 T cells. PLoS One (2012) 7(7):e42170. doi:10.1371/journal.pone. 0042170

107. Mandraju R, Murray S, Forman J, Pasare C. Differential ability of surface and endosomal TLRs to induce CD8 T cell responses in vivo. J Immunol (2014) 192(9):4303-15. doi:10.4049/jimmunol.1302244

108. Chalifour A, Jeannin P, Gauchat JF, Blaecke A, Malissard M, N'Guyen T, et al. Direct bacterial protein PAMP recognition by human NK cells involves TLRs and triggers alpha-defensin production. Blood (2004) 104(6):1778-83. doi:10.1182/blood-2003-08-2820

109. Sivori S, Falco M, Della Chiesa M, Carlomagno S, Vitale M, Moretta L, et al. CpG and double-stranded RNA trigger human NK cells by toll-like receptors: induction of cytokine release and cytotoxicity against tumors and dendritic cells. Proc Natl Acad Sci U S A (2004) 101(27):10116-21. doi:10.1073/pnas.0403744101

110. Hart OM, Athie-Morales V, O'Connor GM, Gardiner CM. TLR7/8-mediated activation of human NK cells results in accessory cell-dependent IFN-gamma production. J Immunol (2005) 175(3):1636-42. doi:10.4049/jimmunol.175.3. 1636

111. Souza-Fonseca-Guimaraes F, Adib-Conquy M, Cavaillon JM. Natural killer (NK) cells in antibacterial innate immunity: angels or devils? Mol Med (2012) 18:270-85. doi:10.2119/molmed.2011.00201

112. Marcenaro E, Ferranti B, Falco M, Moretta L, Moretta A. Human NK cells directly recognize Mycobacterium bovis via TLR2 and acquire the ability to kill monocyte-derived DC. Int Immunol (2008) 20(9):1155-67. doi:10.1093/ intimm/dxn073

113. Bellora F, Castriconi R, Dondero A, Pessino A, Nencioni A, Liggieri G, et al. TLR activation of tumor-associated macrophages from ovarian cancer patients triggers cytolytic activity of NK cells. Eur J Immunol (2014) 44(6):1814-22. doi:10.1002/eji.201344130

114. Kim M, Osborne NR, Zeng W, Donaghy H, McKinnon K, Jackson DC, et al. Herpes simplex virus antigens directly activate NK cells via TLR2, thus facilitating their presentation to CD4 T lymphocytes. J Immunol (2012) 188(9):4158-70. doi:10.4049/jimmunol.1103450

115. Lu H, Dietsch GN, Matthews MA, Yang Y, Ghanekar S, Inokuma M, et al. VTX2337 is a novel TLR8 agonist that activates NK cells and augments ADCC. Clin Cancer Res (2012) 18(2):499-509. doi:10.1158/1078-0432.CCR-11-1625

116. Mokuno Y, Matsuguchi T, Takano M, Nishimura H, Washizu J, Ogawa T, et al. Expression of toll-like receptor 2 on gamma delta $\mathrm{T}$ cells bearing invariant $\mathrm{V}$ gamma 6/V delta 1 induced by Escherichia coli infection in mice. J Immunol (2000) 165(2):931-40. doi:10.4049/jimmunol.165.2.931

117. Deetz CO, Hebbeler AM, Propp NA, Cairo C, Tikhonov I, Pauza CD. Gamma interferon secretion by human Vgamma2Vdelta2 $\mathrm{T}$ cells after stimulation with antibody against the T-cell receptor plus the toll-like receptor 2 agonist Pam3Cys. Infect Immun (2006) 74(8):4505-11. doi:10.1128/IAI.00088-06

118. Martin B, Hirota K, Cua DJ, Stockinger B, Veldhoen M. Interleukin-17producing gammadelta $\mathrm{T}$ cells selectively expand in response to pathogen products and environmental signals. Immunity (2009) 31(2):321-30. doi:10.1016/ j.immuni.2009.06.020

119. Schwacha MG, Daniel T. Up-regulation of cell surface toll-like receptors on circulating gammadelta T-cells following burn injury. Cytokine (2008) 44(3):328-34. doi:10.1016/j.cyto.2008.09.001

120. Schwacha MG, Rani M, Zhang Q, Nunez-Cantu O, Cap AP. Mitochondrial damage-associated molecular patterns activate gammadelta T-cells. Innate Immun (2014) 20(3):261-8. doi:10.1177/1753425913488969

121. Hedges JF, Lubick KJ, Jutila MA. Gamma delta T cells respond directly to pathogen-associated molecular patterns. J Immunol (2005) 174(10):6045-53. doi:10.4049/jimmunol.174.10.6045

122. Wesch D, Beetz S, Oberg HH, Marget M, Krengel K, Kabelitz D. Direct costimulatory effect of TLR3 ligand poly(I:C) on human gamma delta T lymphocytes. J Immunol (2006) 176(3):1348-54. doi:10.4049/jimmunol.176.3.1348

123. Zhang SY, Jouanguy E, Ugolini S, Smahi A, Elain G, Romero P, et al. TLR3 deficiency in patients with herpes simplex encephalitis. Science (2007) 317(5844):1522-7. doi:10.1126/science.1139522

124. Pietschmann K, Beetz S, Welte S, Martens I, Gruen J, Oberg HH, et al. Toll-like receptor expression and function in subsets of human gammadelta T lymphocytes. Scand J Immunol (2009) 70(3):245-55. doi:10.1111/j.1365-3083.2009. 02290.x
125. Paleja B, Anand A, Chaukar D, D’Cruz A, Chiplunkar S. Decreased functional response to toll like receptor ligands in patients with oral cancer. Hum Immunol (2013) 74(8):927-36. doi:10.1016/j.humimm.2013.04.018

126. Shimura $\mathrm{H}$, Nitahara A, Ito A, Tomiyama K, Ito M, Kawai K. Up-regulation of cell surface toll-like receptor 4-MD2 expression on dendritic epidermal T cells after the emigration from epidermis during cutaneous inflammation. J Dermatol Sci (2005) 37(2):101-10. doi:10.1016/j.jdermsci.2004.11.006

127. Cairns B, Maile R, Barnes CM, Frelinger JA, Meyer AA. Increased toll-like receptor 4 expression on $\mathrm{T}$ cells may be a mechanism for enhanced $\mathrm{T}$ cell response late after burn injury. J Trauma (2006) 61(2):293-8; discussion 298-9. doi:10.1097/01.ta.0000228969.46633.bb

128. Chow JC, Young DW, Golenbock DT, Christ WJ, Gusovsky F. Toll-like receptor4 mediates lipopolysaccharide-induced signal transduction. J Biol Chem (1999) 274(16):10689-92. doi:10.1074/jbc.274.16.10689

129. Yang RB, Mark MR, Gray A, Huang A, Xie MH, Zhang M, et al. Toll-like receptor-2 mediates lipopolysaccharide-induced cellular signalling. Nature (1998) 395(6699):284-8. doi:10.1038/26239

130. Cui Y, Kang L, Cui L, He W. Human gammadelta T cell recognition of lipid A is predominately presented by CD1b or CD1c on dendritic cells. Biol Direct (2009) 4:47. doi:10.1186/1745-6150-4-47

131. Wang X, Sun R, Wei H, Tian Z. High-mobility group box 1 (HMGB1)-tolllike receptor (TLR)4-interleukin (IL)-23-IL-17A axis in drug-induced damageassociated lethal hepatitis: interaction of gammadelta T cells with macrophages. Hepatology (2013) 57(1):373-84. doi:10.1002/hep.25982

132. Peng G, Wang HY, Peng W, Kiniwa Y, Seo KH, Wang RF. Tumor-infiltrating gammadelta $\mathrm{T}$ cells suppress $\mathrm{T}$ and dendritic cell function via mechanisms controlled by a unique toll-like receptor signaling pathway. Immunity (2007) 27(2):334-48. doi:10.1016/j.immuni.2007.05.020

133. Choudhary A, Davodeau F, Moreau A, Peyrat MA, Bonneville M, Jotereau F. Selective lysis of autologous tumor cells by recurrent gamma delta tumor-infiltrating lymphocytes from renal carcinoma. J Immunol (1995) 154(8):3932-40.

134. Peng G, Guo Z, Kiniwa Y, Voo KS, Peng W, Fu T, et al. Toll-like receptor 8-mediated reversal of CD4+ regulatory T cell function. Science (2005) 309(5739):1380-4. doi:10.1126/science.1113401

135. Ye J, Ma C, Hsueh EC, Eickhoff CS, Zhang Y, Varvares MA, et al. Tumor-derived gammadelta regulatory $\mathrm{T}$ cells suppress innate and adaptive immunity through the induction of immunosenescence. J Immunol (2013) 190(5):2403-14. doi:10.4049/jimmunol.1202369

136. Ismaili J, Olislagers V, Poupot R, Fournié JJ, Goldman M. Human gamma delta $\mathrm{T}$ cells induce dendritic cell maturation. Clin Immunol (2002) 103(3 Pt 1):296-302. doi:10.1006/clim.2002.5218

137. Conti L, Casetti R, Cardone M, Varano B, Martino A, Belardelli F, et al. Reciprocal activating interaction between dendritic cells and pamidronate-stimulated gammadelta T cells: role of CD86 and inflammatory cytokines. J Immunol (2005) 174(1):252-60. doi:10.4049/jimmunol.174.1.252

138. Leslie DS, Vincent MS, Spada FM, Das H, Sugita M, Morita CT, et al. CD1mediated gamma/delta T cell maturation of dendritic cells. J Exp Med (2002) 196(12):1575-84. doi:10.1084/jem.20021515

139. Shrestha N, Ida JA, Lubinski AS, Pallin M, Kaplan G, Haslett PA. Regulation of acquired immunity by gamma delta T-cell/dendritic-cell interactions. Ann N Y Acad Sci (2005) 1062:79-94. doi:10.1196/annals.1358.011

140. Fang H, Welte T, Zheng X, Chang GJ, Holbrook MR, Soong L, et al. Gammadelta $\mathrm{T}$ cells promote the maturation of dendritic cells during West Nile virus infection. FEMS Immunol Med Microbiol (2010) 59(1):71-80. doi:10.1111/j.1574-695X.2010.00663.x

141. Fowler DW, Copier J, Dalgleish AG, Bodman-Smith MD. Tripartite immune cell co-operation in the bacillus Calmette Guerin-induced activation of gammadelta T cells. Immunol Cell Biol (2013) 91 (7):461-8. doi:10.1038/icb.2013.30

142. Dhar S, Chiplunkar SV. Lysis of aminobisphosphonate-sensitized MCF-7 breast tumor cells by Vgamma9Vdelta2 T cells. Cancer Immun (2010) 10:10.

143. D’Asaro M, La Mendola C, Di Liberto D, Orlando V, Todaro M, Spina $\mathrm{M}$, et al. $\mathrm{V}$ gamma $9 \mathrm{~V}$ delta $2 \mathrm{~T}$ lymphocytes efficiently recognize and kill zoledronate-sensitized, imatinib-sensitive, and imatinib-resistant chronic myelogenous leukemia cells. J Immunol (2010) 184(6):3260-8. doi:10.4049/ jimmunol.0903454

144. Chargui J, Combaret V, Scaglione V, Iacono I, Péri V, Valteau-Couanet D, et al. Bromohydrin pyrophosphate-stimulated Vgamma9delta2 $\mathrm{T}$ cells expanded 
ex vivo from patients with poor-prognosis neuroblastoma lyse autologous primary tumor cells. J Immunother (2010) 33(6):591-8. doi:10.1097/CJI. 0b013e3181dda207

145. Gogoi D, Chiplunkar SV. Targeting gamma delta T cells for cancer immunotherapy: bench to bedside. Indian J Med Res (2013) 138(5):755-61.

146. Weeratna RD, Makinen SR, McCluskie MJ, Davis HL. TLR agonists as vaccine adjuvants: comparison of CpG ODN and resiquimod (R-848). Vaccine (2005) 23(45):5263-70. doi:10.1016/j.vaccine.2005.06.024

147. Kalyan S, Wesch D, Kabelitz D. Aminobisphosphonates and toll-like receptor ligands: recruiting Vgamma9Vdelta2 $\mathrm{T}$ cells for the treatment of hematologic malignancy. Curr Med Chem (2011) 18(34):5206-16. doi:10.2174/ 092986711798184280

148. Paulos CM, Kaiser A, Wrzesinski C, Hinrichs CS, Cassard L, Boni A, et al. Toll-like receptors in tumor immunotherapy. Clin Cancer Res (2007) 13(18 Pt 1):5280-9. doi:10.1158/1078-0432.CCR-07-1378

149. Smits EL, Ponsaerts P, Berneman ZN, Van Tendeloo VF. The use of TLR7 and TLR8 ligands for the enhancement of cancer immunotherapy. Oncologist (2008) 13(8):859-75. doi:10.1634/theoncologist.2008-0097

150. Yu L, Chen S. Toll-like receptors expressed in tumor cells: targets for therapy. Cancer Immunol Immunother (2008) 57(9):1271-8. doi:10.1007/s00262-0080459-8

151. Conroy H, Marshall NA, Mills KH. TLR ligand suppression or enhancement of Treg cells? A double-edged sword in immunity to tumours. Oncogene (2008) 27(2):168-80. doi:10.1038/sj.onc.1210910

152. Ridnour LA, Cheng RY, Switzer CH, Heinecke JL, Ambs S, Glynn S, et al. Molecular pathways: toll-like receptors in the tumor microenvironment - poor prognosis or new therapeutic opportunity. Clin Cancer Res (2013) 19(6):1340-6. doi:10.1158/1078-0432.CCR-12-0408

153. Inatsuka C, Yang Y, Gad E, Rastetter L, Disis ML, Lu H. Gamma delta T cells are activated by polysaccharide $\mathrm{K}$ (PSK) and contribute to the antitumor effect of PSK. Cancer Immunol Immunother (2013) 62(8):1335-45. doi:10.1007/s00262-013-1436-4

154. Hiromatsu K, Yoshikai Y, Matsuzaki G, Ohga S, Muramori K, Matsumoto $\mathrm{K}$, et al. A protective role of gamma/delta $\mathrm{T}$ cells in primary infection with Listeria monocytogenes in mice. J Exp Med (1992) 175(1):49-56. doi:10.1084/ jem.175.1.49

155. Hara T, Mizuno Y, Takaki K, Takada H, Akeda H, Aoki T, et al. Predominant activation and expansion of $\mathrm{V}$ gamma 9-bearing gamma delta $\mathrm{T}$ cells in vivo as well as in vitro in Salmonella infection. J Clin Invest (1992) 90(1):204-10. doi:10.1172/JCI115837

156. Kühl AA, Pawlowski NN, Grollich K, Loddenkemper C, Zeitz M, Hoffmann JC. Aggravation of intestinal inflammation by depletion/deficiency of gammadelta T cells in different types of IBD animal models. J Leukoc Biol (2007) 81(1):168-75. doi:10.1189/jlb.1105696

157. Poccia F, Agrati C, Martini F, Capobianchi MR, Wallace M, Malkovsky M. Antiviral reactivities of gammadelta T cells. Microbes Infect (2005) 7(3):518-28. doi:10.1016/j.micinf.2004.12.009
158. Inoue T, Yoshikai Y, Matsuzaki G, Nomoto K. Early appearing gamma/deltabearing $\mathrm{T}$ cells during infection with Calmette Guerin bacillus. J Immunol (1991) 146(8):2754-62.

159. Beetz S, Wesch D, Marischen L, Welte S, Oberg HH, Kabelitz D. Innate immune functions of human gammadelta T cells. Immunobiology (2008) 213(3-4):173-82. doi:10.1016/j.imbio.2007.10.006

160. Zheng J, Liu Y, Lau YL, Tu W. Gammadelta-T cells: an unpolished sword in human anti-infection immunity. Cell Mol Immunol (2013) 10(1):50-7. doi:10.1038/cmi.2012.43

161. Ribot JC, Chaves-Ferreira M, d'Orey F, Wencker M, Gonçalves-Sousa N, Decalf $\mathrm{J}$, et al. Cutting edge: adaptive versus innate receptor signals selectively control the pool sizes of murine IFN-gamma- or IL-17-producing gammadelta T cells upon infection. J Immunol (2010) 185(11):6421-5. doi:10.4049/jimmunol. 1002283

162. Born WK, Zhang L, Nakayama M, Jin N, Chain JL, Huang Y, et al. Peptide antigens for gamma/delta T cells. Cell Mol Life Sci (2011) 68(14):2335-43. doi:10.1007/s00018-011-0697-3

163. Nedellec S, Bonneville M, Scotet E. Human Vgamma9Vdelta2 T cells: from signals to functions. Semin Immunol (2010) 22(4):199-206. doi:10.1016/j.smim. 2010.04.004

164. Qin G, Mao H, Zheng J, Sia SF, Liu Y, Chan PL, et al. Phosphoantigen-expanded human gammadelta $\mathrm{T}$ cells display potent cytotoxicity against monocytederived macrophages infected with human and avian influenza viruses. J Infect Dis (2009) 200(6):858-65. doi:10.1086/605413

165. Goldinger SM, Dummer R, Baumgaertner P, Mihic-Probst D, Schwarz K, Hammann-Haenni A, et al. Nano-particle vaccination combined with TLR7 and -9 ligands triggers memory and effector CD8(+) T-cell responses in melanoma patients. Eur J Immunol (2012) 42(11):3049-61. doi:10.1002/eji. 201142361

Conflict of Interest Statement: The authors declare that the research was conducted in the absence of any commercial or financial relationships that could be construed as a potential conflict of interest.

Received: 27 May 2014; accepted: 15 July 2014; published online: 31 July 2014.

Citation: Dar AA, Patil RS and Chiplunkar SV (2014) Insights into the relationship between toll like receptors and gamma delta T cell responses. Front. Immunol. 5:366. doi: $10.3389 /$ fimmu.2014.00366

This article was submitted to Tumor Immunity, a section of the journal Frontiers in Immunology.

Copyright $(02014$ Dar, Patil and Chiplunkar. This is an open-access article distributed under the terms of the Creative Commons Attribution License (CC BY). The use, distribution or reproduction in other forums is permitted, provided the original author(s) or licensor are credited and that the original publication in this journal is cited, in accordance with accepted academic practice. No use, distribution or reproduction is permitted which does not comply with these terms. 